\title{
A Review on Solar Radiation Assessment and Forecasting in Algeria (Part 1: Solar Radiation Assessment)
}

\author{
Nourdine Kabouche ${ }^{2,3}$, Farouk Chellali ${ }^{1,2}$, Abdelmadjid Recioui ${ }^{2}$ \\ 1-Département d'électromécanique, Faculté de science et technologie, Université de Djelfa. \\ 2- Signals and Systems Laboratory, Institute of Electrical and Electronic Engineering, University M'hamed \\ Bougara of Boumerdes, Algeria. \\ 3-Centre de développement des énergies renouvelables, CDER, 16340, Algiers, Alegria. \\ f.chellali@univ-djelfa.dz
}

\begin{abstract}
Solar energy takes a prime place in the energetic transition towards renewable energies. Solar radiation data plays a major role in the expansion of this energy. However, the unavailability of these data due to the reduced number of meteorological stations has imposed the use of various solar radiation estimation and prediction models. Moreover, the geostrategic location of Algeria, its enormous area and its huge solar potential places it among the promising solar energy countries. The main objective of this part is to review the studies done upon estimation and assessment of solar radiation for Algerian sites. Different techniques are proposed including semi-empirical models, satellite imaging and solar maps. The study shows that semiempirical models have been the most widely used due to the unavailability of solar data.
\end{abstract}

Keywords: Solar energy, solar radiation model, solar radiation estimation; solar map.

Contents

1- Introduction.

2- solar potential sources of data

3- In situ measurements

4- Semi-empirical and parametric models

5- Remote sensing and satellite images

6- Solar maps

7- Classification and Clustering of Solar Radiation Data.

8- Conclusion.

\section{INTRODUCTION}

Recently, renewable energy has become a major area of interest in the field of energy production for several economic and environmental considerations, in addition to the emergence of several indicators for approaching the depletion of fossil fuels. In Algeria, the issue of renewable energy has received considerable critical attention by many academics and industrials due to the Algerian current policy of energy. This strategic choice is motivated by the immense renewable energy potential especially in the Algeria Sahara. Indeed, solar energy constitutes the major axis of the ambitious Algerian national program of energy that devotes an important budget to the solar thermal and solar photovoltaic resources; By 2030 , solar energy should reach more than $37 \%$ of the national electricity production [1]. Under these circumstances, evaluating the solar radiation for various fields of renewable energies such as thermal energy, photovoltaic energy, solar water heaters, solar fruit dryers, as well as thermal insulation applications in desert houses is of great importance. The assessment of solar radiation is of utmost importance to identify the walls that need to be isolated in addition to the selection of the quality of building materials used [2].

During the past 30 years, much more information has become available on solar radiation in Algeria due to the fact that several studies investigating solar radiation components and behaviors have been carried out. In this paper, a review of the researches conducted on the assessment of solar radiation in Algeria is proposed. In fact, this topic is one of the most active research areas in Algeria as a preliminary and basic phase before determining the appropriate chooses and sizes for the explorative systems. Quantification of solar potential has been investigated by academics and industrials via several approaches including mapping, classification, forecasting, empirical and theoretical modeling. From a general overview on solar energy literature in Algeria, five main approaches have been distinguished. The first approach, in situ assessment, relies on local measurements. The second approach is based on solar potential modeling. In this approach, empirical, semi-empirical and pure theoretical models have been recognized. As another 
alternative, satellite based models have also been investigated to respond to the issue of remote and large area solar potential assessment. Obviously, solar potential maps constitute an ultimate consequence of resource assessment due to their importance in the solar energy industry. The last approach discussed in this work is the forecasting and the prediction of solar radiations.

Prior to commencing the review, a general description of the Algerian territory seems necessary; Algeria is the tenth country in the world in term of surface with an area of $2,381,741 \mathrm{~km}^{2}$. As illustrated in table 1 , the Algerian territory is divided into three geographical and climatic zones that are the costal, interior and Saharian zones. The coastal zone occupies only $4 \%$ of the global territory and it is characterized by a high populations' density. In terms of climate, coastal region are characterized by a Mediterranean climate with moderate rainfall winter and humid summer. The interior zone is located toward the south and it is mostly characterized by Highlands. Most agricultural activities are confined in these Highlands that represent $10 \%$ of the global area and finally comes the semi-empty Saharian zone, which occupies $86 \%$ of the global territory (around 2 million $\mathrm{km}^{2}$ ). This later is characterized by an enormous solar potential particularly the zone around the orbit of the Cancer, which is spread over $1800 \mathrm{~km}$.

Table 1.General Algerian territory information[3,4].

\begin{tabular}{|c|c|c|c|}
\hline & Coast & Highlands & Sahara \\
\hline Surface (\%) & 4 & 10 & 86 \\
\hline Upper & $37^{\circ} \mathrm{N}$ & $34^{\circ} \mathrm{N}$ & $32^{\circ} \mathrm{N}$ \\
\hline longitude & $34^{\circ} \mathrm{N}$ & $32^{\circ} \mathrm{N}$ & $18.6^{\circ} \mathrm{N}$ \\
\hline Lower & 95270 & 238174 & 2048297 \\
\hline $\begin{array}{l}\text { longitude } \\
\text { Area }\left(\mathrm{km}^{2}\right) \\
\text { Mean dailv }\end{array}$ & 7.26 & 8.22 & 9.59 \\
\hline $\begin{array}{l}\text { sunshine } \\
\text { duration }(h)\end{array}$ & 2650 & 3000 & 3500 \\
\hline $\begin{array}{l}\text { Average } \\
\text { duration of }\end{array}$ & & & \\
\hline $\begin{array}{l}\text { sunshine } \\
\text { (h/year) }\end{array}$ & 1700 & 1900 & 2650 \\
\hline $\begin{array}{l}\text { Received } \\
\text { average } \\
\text { energy } \\
\left(\mathrm{kWh} / \mathrm{m}^{2} / \text { year }\right)\end{array}$ & 4.66 & 5.21 & 7.26 \\
\hline $\begin{array}{l}\text { Solar daily } \\
\text { energy density } \\
\left(\mathrm{kWh} / \mathrm{m}^{2}\right) \\
\text { Potential daily } \\
\text { energy }(T W h)\end{array}$ & 443.96 & 1240.89 & 14870.63 \\
\hline
\end{tabular}

In addition to some general information of the Algerian territory, table 1 presents some solar parameters for each zone such as sunshine duration and received energies averages. As it can be noticed, Saharian zone is characterized the highest sunshine duration and energies. However, the solar potential in the north should not be underestimated because it is of high potential when compared to those in Europe and North America.

\section{SOLAR POTENTIAL SOURCES OF DATA}

The National Meteorological Office (NMO) of Algeria is considered to be the main source of meteorological data for academia as well as industrial purposes. Within 75 meteorological stations distributed mainly in the north[5], only 28 stations are equipped with direct or indirect solar measurement apparatus as indicated in figure 1[6-8]. By direct solar radiation measurement, we refer to the measurement of Global and Diffuse radiation via pyrometers. However, the indirect solar radiation measurement means merely sunshine measurements. In addition to the locations of the ONM meteorological stations, figure 1 presents information about the considered sites as well as other meteorological stations that do not belong to the ONM network.

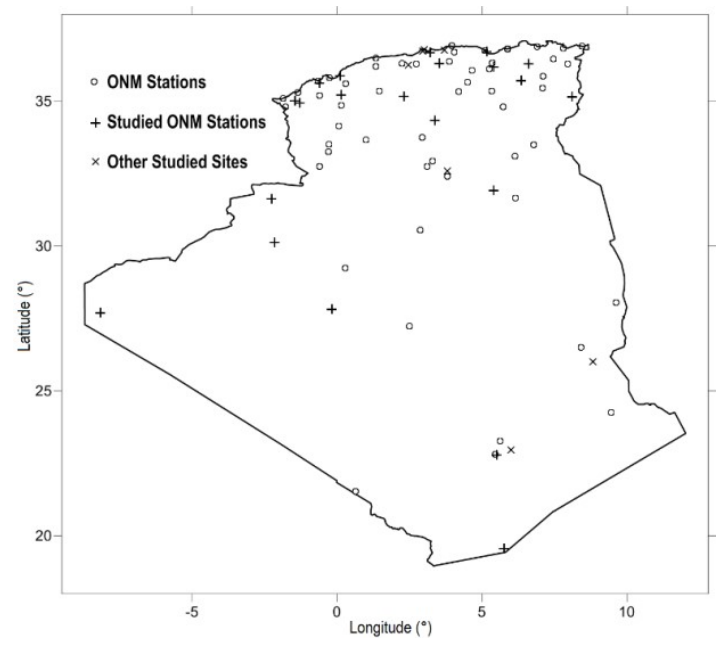

Fig.1Studied and non-studied Algerian sites

In Addition to NMO, some research institutions and universities have their own stations such as the Center of development of renewable energies (CDER) which is equipped with three sun trackers located at 
the Capital, Ghardaïa and Adrar cities, respectively.

It is worth mentioning that the stations equipped by sun-truckers are rare because of their cost (They count around 1000 across the world) [8].

\section{IN SITU MEASUREMENTS}

In-situ potential assessments are the most accurate methods for the quantification of solar potential at a given location. With these methods, potential quantification is very accurate especially when accurate sensors are used. Errors in these methods can be induced by sensors precisions or the sampling and quantification process of acquisition systems. However, the major inconvenience with in-situ measurements is their space limitations as well as the equipment's cost such as sun trackers, pyrometers and data acquisition cards. Indeed, the number of radiometric stations over the world is restricted to only about one thousand radiometric stations[8].In Algeria, only four sites are equipped with full radiometric stations, which are Algiers; the capital, Ghardaïa, Adrar and Tamanrasset. Such stations offer the opportunity of direct measurements of the Direct Normal Irradiation (DNI) and the Diffused Horizontal Irradiation (DHI) thanks to its tracking mechanism (Figure 2).
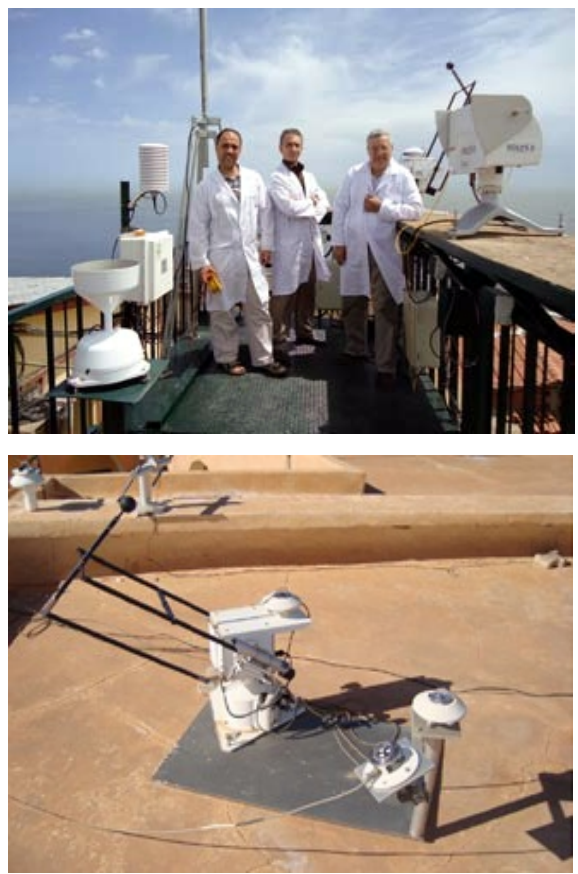

Fig. 2 Sun trackers of Algiers and Ghardaïa stations, CDER
For the site of Bouzeréah; Algiers, assessment of $\mathrm{GHI}$ and $\mathrm{DHI}$ have been a subject of many studies in 1985.Currently in Algeria, there are four radiometric stations equipped with Sun trackers capable to measure the $\mathrm{GHI}$, DNI and $\mathrm{DHI}$ with high precision. Algeria counts about 75 meteorological stations distributed mainly in the northern part. There are only seven of them that measure solar radiation. Moreover, since the measurements of these stations are accurate only in an area of $30 \mathrm{~km}$ around it, most of the desert zones are still uncovered or partially covered[9-11]. This small number of stations measuring the solar radiation components is due to the high prices of the specified instruments and their calibration problem.

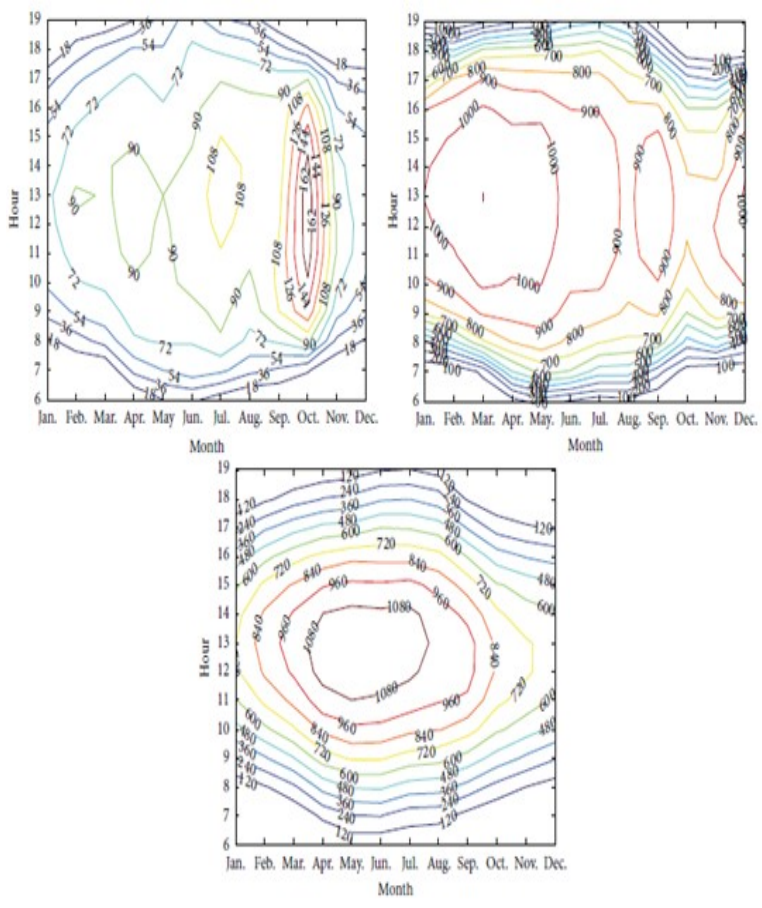

Fig. 3 Contours of hourly solar radiation components distribution, diffuse (top left), DNI (top right), Global (bottom) [12].

Gairaa et al. identify the solar energy potential in Ghardaïa by examining solar radiation components, clearness index and sunshine fraction. This study conducted to an annual global and direct solar radiation of $2118 \mathrm{kWh} / \mathrm{m}^{2}$ and $2067 \mathrm{kWh} / \mathrm{m}^{2}$ respectively [12]. In [13], the authors provide solar radiations contours and the surface temperature measurements in Ghardaïa during the year 2005. As indicated in figure 3, the authors have established distributions of the three components of solar radiation (Direct, diffuse and global) in form of 
contours. In addition to that, Gairaa et al. have compared their results with a 22-year average data provided by NASA. It has been found that the maximum monthly average solar radiation is $1268 \mathrm{~W} / \mathrm{m}^{2}$ while the yearly average energy is $21.83 \mathrm{MJ} / \mathrm{m}^{2} /$ day. In [14], Gairaa et al. used 3 year data to examine the solar radiation in Ghardaïa. In this work, the authors presented a full series of the hourly, monthly annual averages and frequency distributions of global and diffuse radiations in addition to the monthly mean daily values of clearness and diffuse indexes. As a conclusion, they stated that Ghardaiia is characterized by a clear sky throughout the year with clearness and diffuses indexes of about 0.68 and 0.37 , respectively.

\section{SEMI-EMPIRICAL AND \\ PARAMETRIC MODELS}

To deal with the aforementioned in situ problems, low-cost measurements such as sunshine duration and semi-empirical and parametric models have been proposed. These models use site's geographic data as well as other meteorological measurements to estimate solar radiation. While meteorological models provide GSR estimation for any type of sky, the semiempirical models are limited to clear sky only. Note that all models listed below are listed in the table $a$ in the appendix
Preliminary work on solar radiation modeling was undertaken by Capderou (1985) who have realized the first solar atlas for Algeria. In fact, this solar atlas came in three volumes that consider theoretical models based on the atmospheric turbidity, tables of hourly and daily solar radiation components for each month at different inclinations and monthly diagrams of solar paths and the shadow line as well as solar maps. It is worth to mention that Capderou has divided Algeria into 8 climatic according to the received solar radiations [15]. With his remarkable work of 1752 pages, Capderou is considered to be the father of solar radiation assessment in Algeria and he is cited practically in all the later works.

When mentioning solar radiation modeling in Algeria, it is necessary to stop at the work of researchers Gairaa and Benkaciali who presented a series of researches that touched on many topics[16-21]. $\ln [16]$, Gairaa et al. have proposed four mathematical models to estimate GSR received on an inclined plane in order to determine the optimum inclination and azimuth for Ghardaïa either on a daily basis or for a specific period of the year. After a comparison with experimental data, the HDKR model was adopted with the best RMSE of 0.0216 .

Table 2 Comparison between measured and estimated monthly global solar radiation $\left(\mathrm{Wh} / \mathrm{m}^{2}\right)$ [17].

\begin{tabular}{llllllllll}
\hline & Measured & Linear & $e(\%)$ & Quadratic & $e(\%)$ & Logarithmic & $e(\%)$ & Exponential & $e(\%)$ \\
\hline January & 3871 & 3879.75 & -0.226 & 3924.54 & -1.383 & 4054.48 & -4.74 & 3812.38 & 1.514 \\
February & 4842 & 4768.92 & 1.509 & 4746.43 & 1.974 & 5229.17 & -7.996 & 4693.99 & 3.057 \\
March & 5926 & 5836.64 & 1.508 & 5863.69 & 1.051 & 6176.79 & -4.232 & 5735.38 & 3.217 \\
April & 7339 & 7346.01 & -0.096 & 7393.31 & -0.74 & 7779.2 & -5.998 & 7261.09 & 1.062 \\
May & 7745 & 7745.06 & -0.001 & 7809.96 & -0.839 & 8203.51 & -5.92 & 7617.16 & 1.651 \\
June & 7812 & 7826.41 & -0.184 & 7930.14 & -1.512 & 8239.29 & -5.47 & 7699.28 & 1.443 \\
July & 7503 & 7492.63 & 0.138 & 7484.43 & 0.248 & 7985.6 & -6.432 & 7437.93 & 0.867 \\
August & 7090 & 7224.91 & -1.903 & 7377.84 & -4.06 & 7576.91 & -6.868 & 7191.04 & -1.425 \\
September & 6036 & 6024.21 & 0.195 & 6054.37 & -0.304 & 6371.7 & -5.562 & 5898.47 & 2.278 \\
October & 4824 & 4821.02 & 0.062 & 4869.69 & -0.947 & 5128.76 & -6.318 & 4737.96 & 1.784 \\
November & 4030 & 4026.13 & 0.096 & 3978.2 & 1.285 & 4224.29 & -4.821 & 3963.04 & 1.662 \\
December & 3437 & 3427.06 & 0.289 & 3626.54 & -5.515 & 3728.76 & -8.489 & 3349.42 & 2.548 \\
\hline
\end{tabular}

In another work[17], Gairaa et al. examined seven empirical models to estimate the HGSR in Ghardaïa. It has been found that the quadratic and the linear models gave the best annual and monthly estimation. Whereas, for meteorological models that uses air temperature, humidity and sun duration fraction, it has been found that Abdalla model was the best ( Table 2).

In another work, Gairaa et al. have examined five empirical models[18]. To estimate the clearness index $\left(K_{T}\right)$ and the diffuse fraction $\left(K_{d}\right)$ on a horizontal plane and other inclined planes. Data of direct, diffuse and global solar radiations recorded during 2005 in Ghardaïa have been used in that work. For $K_{T}$ estimation, the mean relative errors did not exceed $0.5 \%$ while for $K_{d}$ estimation the polynomial model gives the best mean correlation coefficient. Estimation results of the global solar radiation are presented in figure 4 . 

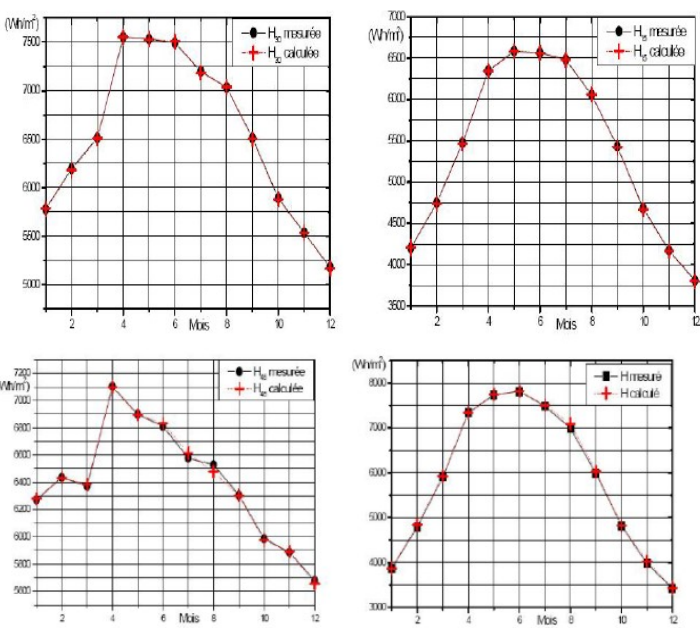

Fig. 4 Measured and estimated monthly mean daily global irradiation for different tilted planes[18].
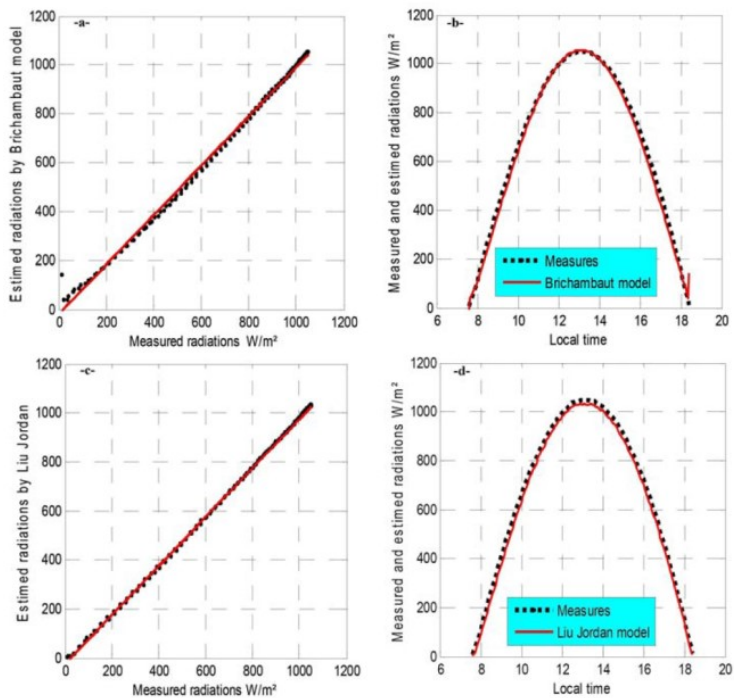

Fig. 5 Measured and estimated global solar irradiation at $32^{\circ}$ tilted plane using two models [21].

Benkaciali et al. have estimated the daily GSR on an inclined plane by the summation of diffuse solar radiation determined from seven empirical models based on a geometrical method. Data of different types of sky measured during 2008 at Ghardaïa have been used for validation. According the average MBE, Temps\&Coulson model gave the best results for any type of sky $[19,20]$. In [21], the authors estimated solar radiation components received on three inclined planes. They have used Brichambaut and Lieu\&Jordan models. According to the relative error between estimated and measured data, the first model gave the best results as indicated in figure 5 that presents a comparison of the measured and estimated global solar irradiation at $32^{\circ}$ tilted plane.

The estimation of GSR for tilted plane has been re-questioned again by Talbiet al [22]. In this work three models have been examined using data from Tamanrasset and Algiers. As results, it has been found that Capderou model is more appropriate as indicated in figure 6, which presents estimation of GSR for clear and cloudy skies. When evoking GSR estimation under different skies, work of Yaiche et al. manifest firmly. In [11], the authors developed an approach to estimate daily global solar radiation received on horizontal plane(HGSR)using only sunshine duration measurements and under all sky conditions. Starting by estimating HGSR for clear sky using Brichambaut model, Yaiche introduced the sunshine fraction to determine the cloud cover factor necessary to calculate HGSR for different sky conditions. The comparison between estimated and real in-situ data of several years yield an error of $7.45 \%$ [11].In [23], the authors have implemented an Excel program based on two clear sky models to estimate solar radiation in 48 Algerian departments. While Brichambaut model was used to estimate solar radiation components on horizontal plane, Liu \&Jordan model was used to estimate global and direct solar radiation at different inclination and normal incidence respectively. In [23], this program has been used to estimate solar radiation components under different types of sky where the cloud attenuation factor has been used to determine the type of sky. In [24], direct solar radiation under clear sky has been introduce. It is worth to mention that validation of the developed models has been done using data of sun-trackers in Ghardaïa and Bouzaerah (Algiers).Figure 7 presents the visual interface of program developed by Yaiche et al. [23].

In 2011, Zaatri et al. have demonstrated that Capderou is the most suitable to fit solar radiation on inclined plane at Constantine city [25]. In this study, two other models have been used for comparison. 


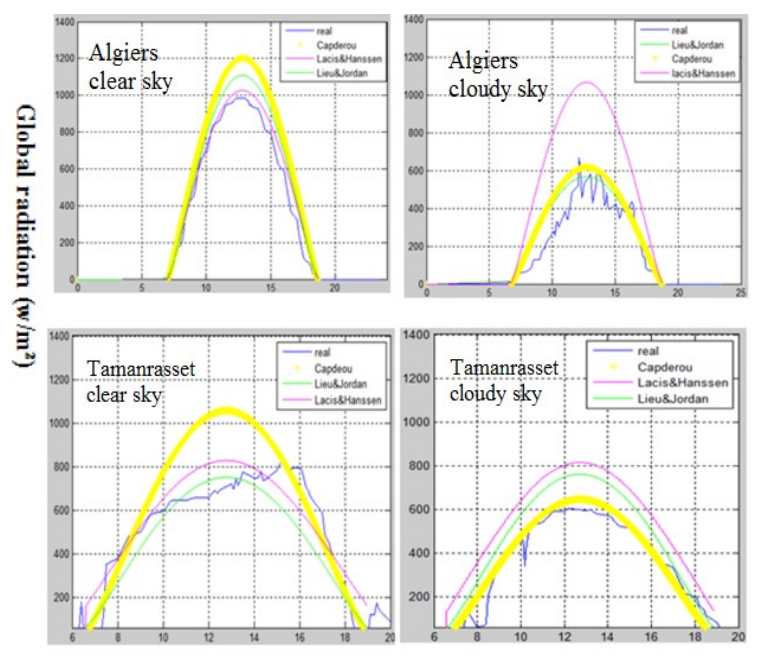

time (h)

Fig. 6 Measured and computed global radiation in Tamanrasset, clear sky (March1992), cloudy sky (March1992) [22].

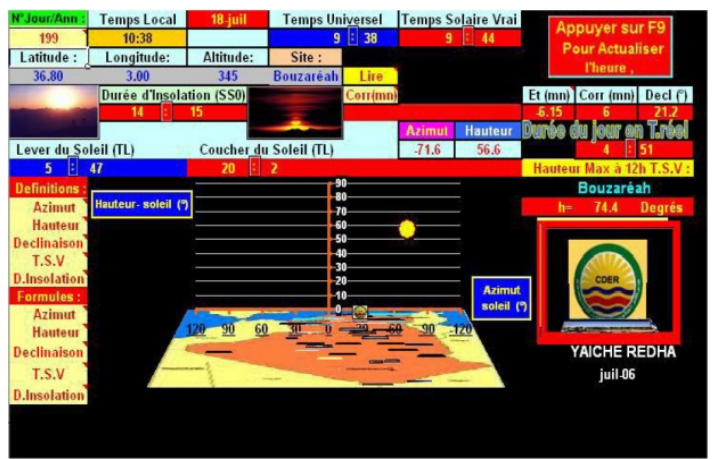

Fig. 7 The visual interface of program developed by Yaiche [23]

Behar et al. have examined 17 solar radiation models under a clear sky to select the most suitable to estimate DNI. For this purpose, four typical days taken from data recorded every 5-minduring 2006 at Ghardaïa have been used. The authors have introduced a new statistical indicator that is the Global Performance Indicator. As shown in figure 8, the ASHRAE model was found to be the best[9].

In an analysis of solar radiation at Ghardaïa and Bouzaréah, Benmouiza et al. have evaluated models of Lacis \& Hansen, Bird \& Hulstrom and Davies \& Hay to estimate hourly data of solar radiation using only over four days [26]. The study concluded that Lacis \& Hansen fits the global radiation data of Ghardaïa while data of Bouzaréah are best fited by Bird \& Hulstrom model as indicated in figure 9. It has been found also that Bird \& Hulstrom and Davies \& Hay models are more suitable to estimate the direct and diffuse radiations.

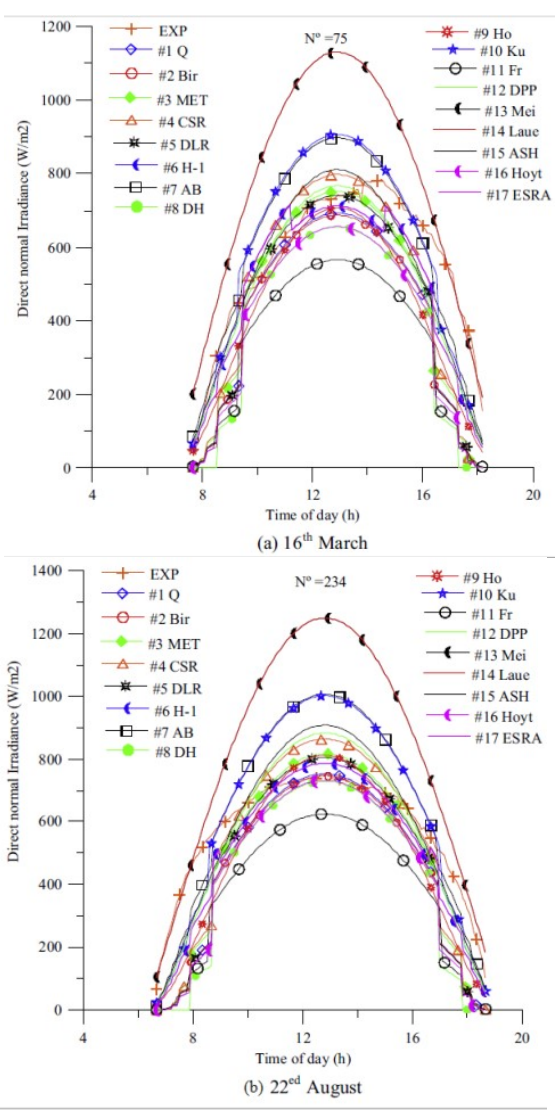

Fig. 8 Measured and predicted DNI using 17 models for two different days [9].
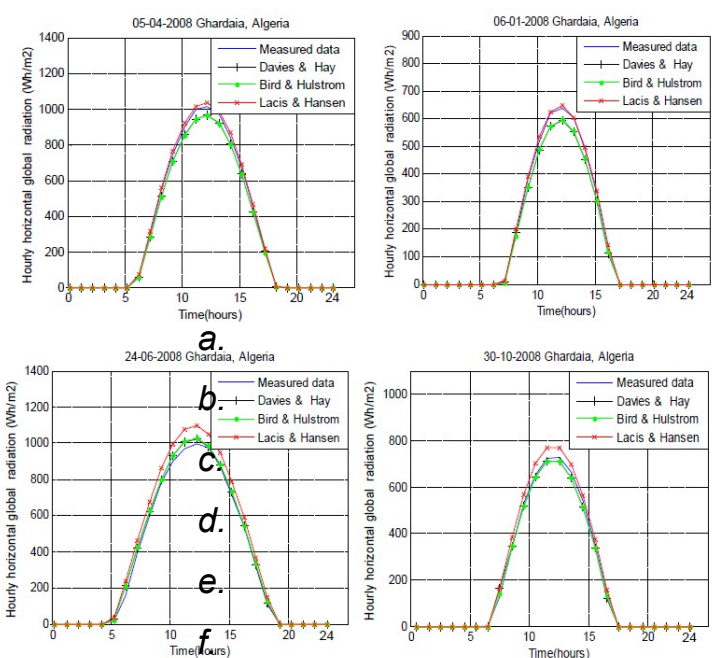

Fig. 9 Measured and estimated hourly horizontal global solar radiation using 3 models for different days in Ghardaiia [26].

Mesriet al. developed a graphical interface to estimate solar radiation at ground level. They have used three meteorological models based mainly on sunshine duration and three semi-empirical models to estimate monthly mean daily and hourly GSR data, 
respectively. Monthly and typical days hourly data measured during 2006 in Ghardaïa have been used to check these models, respectively. It has been found that Lui \& Jordon and Garg models are most suitable to estimate the hourly GSR and monthly mean daily GSR, respectively [27].In [28], five empirical models to estimate daily GSR on an inclined plane have been examined and validated using 5 years data measurements recorded at Algiers and Ghardaïa. The average relative error between measurements and estimations, for one day per season, has shown that Liu \& Jordan model is more suitable as indicated in figure 10. In [29], four semi-empirical models to estimate solar radiation components have been used. Hourly data measured at Bouzaréah and Ghardaïa; on specific days have been used. It has been found that Davies \& Hay and Bird \&Hulstrom yielded the best estimation.

Asradj et al. have used four linear regression models (Angstrom-Prescott, Bahel Newland, and Abdalla) to estimate the GSR at Bejaia site. They showed that Bahel model was the best with an RMSE of 7.6889 [30].

In [31,32], Bouzid et al. have estimated the hourly GSR on inclined plane, after estimating hourly solar radiation components on horizontal plane using three semiempirical models. Then, they have used a genetic algorithm to find the best configuration of an autonomous photovoltaic (PV) system applied to Bechar and Tlemcen sites.
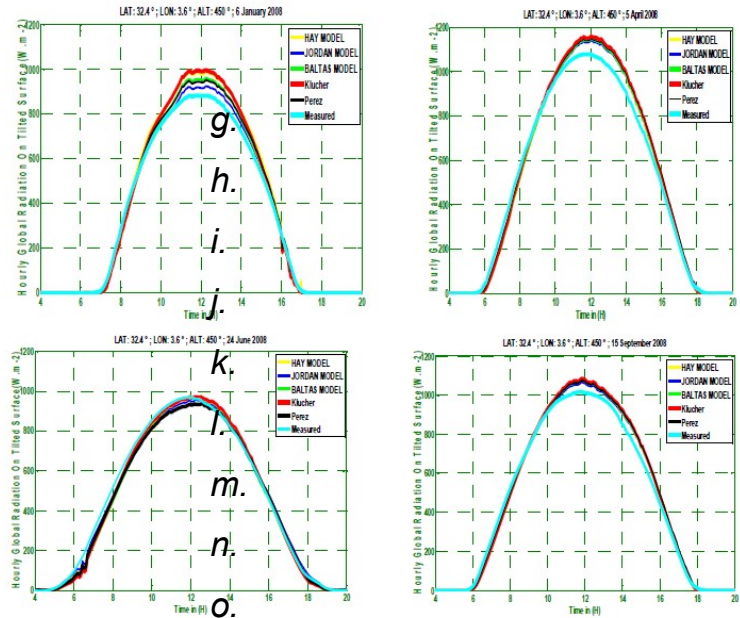

Fig. 10 Measured and estimated hourly horizontal global solar radiation using 5 models for different days in Ghardaïa[ 28].

Mecibah et al. have proposed a methodology to estimate the hourly, monthly mean daily, monthly and annual direct solar radiation, regardless the availability or not of diffuse and GSR measurements. Then, they have found that compared to measurements in Algiers, Ghardaiia and Tamanrasset, the estimated data gave better results than those provided by five spatial databases, especially for the monthly averages values where an RMSE of 0.491 was obtained for the site of Ghardaïa [33]. In [34], 11 empirical models have been studied, correlating the monthly mean daily HGSR with air temperature and monthly mean sunshine duration, at 6 Algerian sites that are Algiers, Oran, Batna, Ghardaïa, Bechar and Tamanrasset (Figure 12). The authors found that models based on sunshine duration are more accurate than those based on temperature are. The best performances for Ghardaiia were obtained for the cubic and quadratic regression models with an RMSE of 0.1118 and 0.1123 , respectively.

In a study which set out to determine the monthly mean daily diffuse solar radiation via monthly mean sunshine duration and GSR, Boukelia et al. have applied ten empirical models-forsix Algerian sites (Algiers, Constantine, Ghardaïa, Bechar, Adrar and Tamanrasset). Statistical tests showed that for Ghardaïa site, the quadratic and cubic equations are more accurate with an RMSE of 0.0706 and 0.0582 , respectively [4].
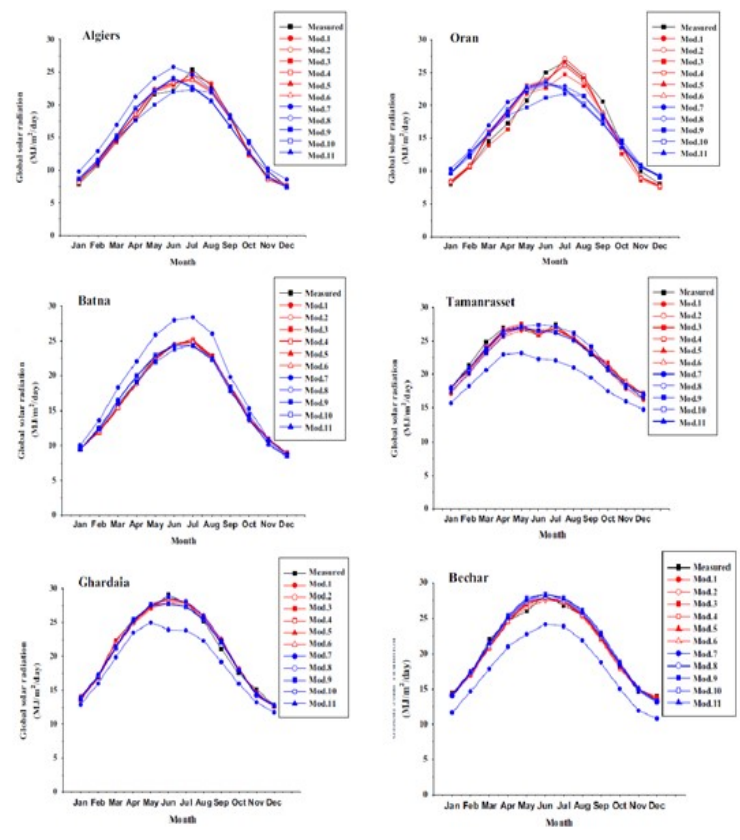

Fig.11 Measured and predicted monthly mean daily global solar irradiation in six Algerian sites

[34]. 
In [35], the authors have determined monthly and annual direct normal solar radiation from monthly mean global and diffuse solar radiation data. Collares-Pereira and Liu \& Jordan models were used to estimate monthly mean hourly global and diffuse solar radiation on a horizontal plane. Measurements taken at three stations-Algiers, Ghardaïa and Tamanrasset-have been used to validate both the estimated and provided NASA-SSE spatial data. It was found that the estimated data were more accurate than the satellite data. In [36], six empirical models based on sunshine duration to estimate monthly mean daily HGSRat Adrar and Beni Abbes have been studied. Seven statistical error indicators showed that the quadratic model is applicable for both sites. In [37], the authors used a simple model to estimate hourly, daily, monthly and annual direct solar radiation with four modes of tracking for the solar concentrator. Global and diffuse on horizontal plane and direct solar radiation, measured at three Algerian sites (Algiers 2009-2011, Ghardaïa 2005-2009, Tamanrasset 1995-2009) have been used. It was found that the estimations were consistent with measurements and the full tracking gave the greatest energy gains. In [38], monthly mean daily global and diffuse solar radiation have been used to determine monthly mean daily direct solar radiation intercepted by solar concentrator with four tracking modes. Table 3 presents five used regression models by boukelia in [4].

Table 3 Regression models based on global solar irradiation[4]

\begin{tabular}{lc}
\hline Models & Equations \\
\hline Linear & $H_{d} / H_{g}=a+b\left(H_{g} / H_{0}\right)$ \\
Quadratic & $H_{d} / H_{g}=a+b\left(H_{g} / H_{0}\right)$ \\
& $+c\left(H_{g} / H_{0}\right)^{2}$ \\
Cubic & $H_{d} / H_{g}=a+b\left(H_{g} / H_{0}\right)$ \\
& $+c\left(H_{g} / H_{0}\right)^{2}$ \\
& $+d\left(H_{g} / H_{0}\right)^{3}$ \\
& \\
Logarithmic & $H_{d} / H_{g}=a+b \log \left(H_{g} / H_{0}\right)$ \\
Exponential & $H_{d} / H_{g}=a e^{b\left(H_{g} / H_{0}\right)}$ \\
\hline
\end{tabular}

In an investigation into GSR modeling, Ouali et al. have proposed a model of GSR for Bejaia site based on meteorological parameters [39]. Solar radiation measurements and five other meteorological parameters recorded every 8 -min have been used (figure 11). Two thirds of data has been used to establish the model and one third for its validation. The comparison with four other models (Angstrom-Prescott, Bahel, Newland and Abdala), reveals that the proposed model gives a better estimate with an MPE of $2.12 \%$.

Detailed examination of eight empirical models by Nia et al. showed that the model combining sunshine duration, mean monthly temperature and mean relative humidity produces the lower RMSE of $1.91 \%$ [40]. This study has been conducted for the site of Algiers, Oran, Bechar and Tamanrasset.

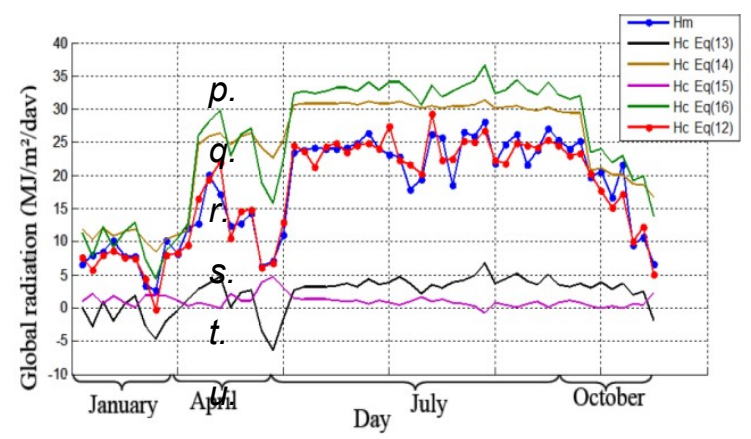

Fig. 12 Measured and calculated monthly mean global solar irradiation using four models [39]

Azzouni et al. have used the models of Liu \& Jordan and Page to determine the global monthly solar radiation received on an inclined plane at three sites (Algiers, Ouargla and Tamanrasset). A comparison between the calculated data and those of solar Atlas of Algeria was carried out in order to validate the proposed approach[41].

Salmi et al. have developed four analytical modelsto estimate the monthly GSR from sunshine duration at Mascara, Algeria. GSR and sunshine duration measured over 3 years (2002-2004) have been used. The authors have found that the highest errors were in April and December and that the exponential model gave the lowest RMSE[42]. In [43], the same study for four sites (Algiers, Oran, Constantine, and Tamanrasset) has been done. GSR and sunshine duration measured over 6 years (2000-2005) have been used. The statistical analysis showed that the models are more suitable for the first two sites. In [44], the authors used three models-Collares Pereira \&Rabl, Gaussian distribution, and H.A.-to calculate the hourly GSR on two Algerian sites (AinBessem and Djelfa). Data recorded between 2000 and 2004 have been used. It was found that the second model is more suitable especially for Djelfa.

Chikh et al. have used the height of sun along with the Liu \& Jordan correlation model to give the hourly diffuse fraction, named $\mathrm{K}_{\mathrm{tcor}}$, as a function of the hourly clearness 
index (figure 13). At least one year of data recorded between 1990 and 1992 at three Algerian sites (Algiers, Bechar, and Tamanrasset) have been used. They have found that this model gave better result than correlation with only clearness index [45-47].

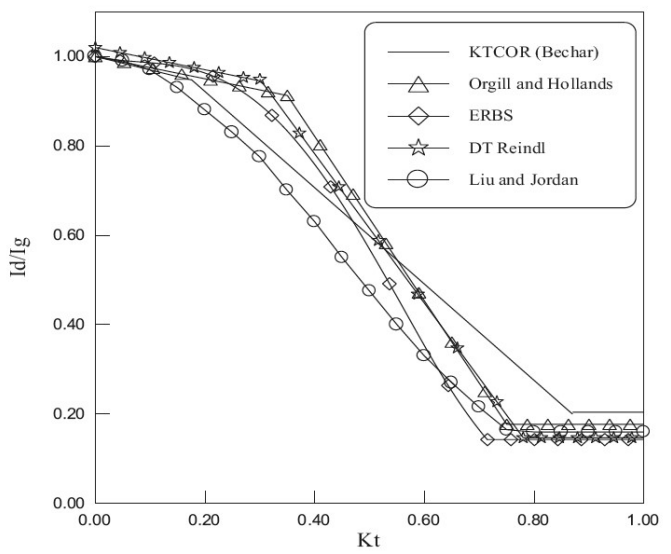

Fig. 13 Correlation of the diffuse fraction given by several authors compared to $\mathrm{K}_{\text {tcor }}$ [46]

In [48],Aksas et al. evaluated the solar potential of Batna site using Brichambaut model. They pretended that this site receives almost $1700 \mathrm{kWh} / \mathrm{m}^{2}$ and $1500 \mathrm{kWh} / \mathrm{m}^{2}$ of global and Beam solar radiation as shown in figure 14.

Hamdani et al. applied three models to estimate GSR on horizontal and inclined planes. Corresponding data measured on January 2, 2009; at Ghardaïa, have been used to choose the suitable model. It has been found that, while Capderou model is suitable for horizontal plane, Brichambaut model is suitable for inclined one [49].

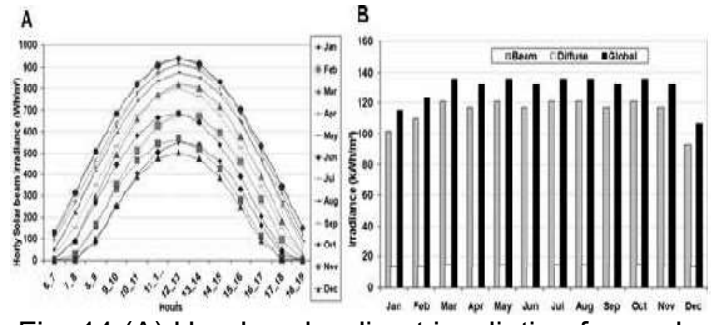

Fig. 14 (A) Hourly solar direct irradiation for each typical day of months; (B) Monthly solar irradiation of Batna site [48]

Koussa et al. studiedseveral models that estimate hourly and monthly mean daily diffuse and GSR on horizontal plane. They retained Rietveld, Garg and McCulloch models to estimate monthly mean daily GSRat Adrar, Bouzaréah and Ghardaïa. The models of Page, Liu \&Jordan and Collares-
Pereira been used for these sites to estimate monthly mean daily diffuse solar radiation. In addition to that, they recommended Jain and Liu \& Jordan models, respectively to reconstitute the hourly global and diffuse solar radiation[50,51]. Figure 15 presents the Hourly distribution of measured and estimated global irradiation using the two proposed models and three studied Algerian sites.

Yettou et al. compared the Brichambaut and the R.Sun models used to estimate solar radiation components on horizontal and on any inclination. Data of specific days measured at Ghardaïa and Bouzaréah have been used to check each model. The obtained relative error indicated that the second model provides better estimation of direct and diffuse solar radiation [52].

In another pioneering study, Mefti et al. used the exponential probability distribution of daily sunshine duration, the Angstrom equation, the beta probability distribution of hourly GSR, the polynomial correlations of the direct and diffuse solar radiation and the Klucher model to generate the hourly solar radiation on an inclined plane. The monthly mean daily sunshine duration recorded at 54 Algerian stations and the hourly solar radiation data of Algiers, Bechar and Tamanrasset have been used in this work. The authors suggested to extend this method to the remaining stations[53].In [54], a critical analysis of the Solar Atlas of Algeria elaborated by Michel Capderou was presented. Capderou have used the atmospheric turbidity to calculate direct and diffuse solar radiation components received on any inclination and for a clear sky. Whereas, for an average sky, these components are calculated using the Brichambaut probabilistic model. To adjust the Capderou model, they have chosen, from literature, the best formulations of atmospheric turbidity and probability distribution function. A database of solar radiation components received on different planes, pressure, temperature and relative humidity, recorded during 1987 at Bouzaréah, as well as daily sunshine duration recorded in Algiers between 1952 and 1988 have been used. This work has improved the accuracy of estimation except for diffuse component. Figure 16 presents the measured and the estimated probability density functions of hourly clearness index for the regions of northern Algeria. 

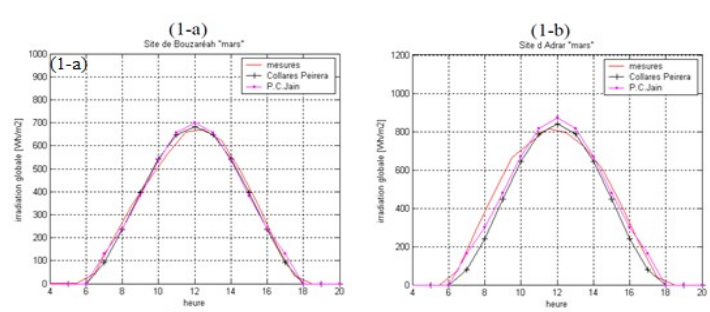

$(1-c)$
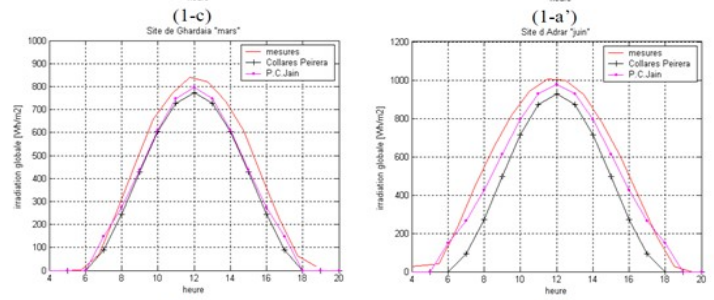

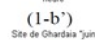
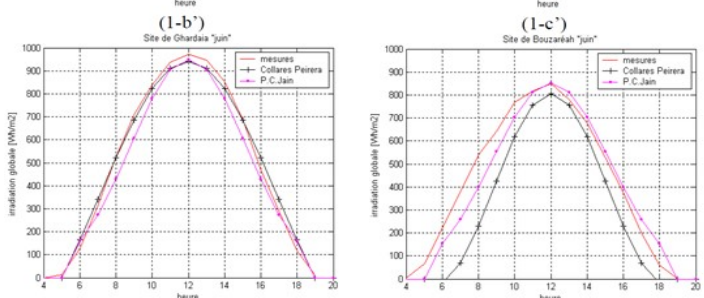

Fig. 15. Hourly distribution of measured and estimated global irradiation using two models and three Algerian sites [51]
Chegaar et al. applied Barbaro; customized by the authors, and Angstrom models to estimate monthly mean daily HGSR at four Algerian sites (Algiers, Oran, Beni Abbas and Tamanrasset). Because of the good agreement between the estimated and experimental data for Algiers, these models were suggested for similar climatic sites[55].In [56], the authors tested a model that requires only sunshine duration and the hour angle at solar noon of the $15^{\text {th }}$ day of each month to estimate monthly mean daily HGSRat four Algerian sites (Algiers, Oran, Bechar and Tamanrasset). They divided the sites on three zones. Then, they determined the appropriate zone parameters for each site. Sunshine duration and GSR data recorded over 25 and about 10years have been used in both studies.

Culmination with this part, a Survey of some bibliographical references using empirical models for solar radiation estimation is presented in table 4.

Table 4 Survey of some bibliographical references using empirical models for solar radiation estimation. ${ }^{*} A M D, M M D$ are annual mean daily, monthly mean daily, TD is typical day. IGSR is the global solar radiation on inclined plane. HDiff is the diffuse solar radiation on horizontal plane

\begin{tabular}{|c|c|c|c|c|c|c|c|c|}
\hline \multirow[t]{2}{*}{ Ref } & \multirow[t]{2}{*}{ Site } & \multirow[t]{2}{*}{ Time step } & \multirow[t]{2}{*}{ Data } & \multirow[t]{2}{*}{ Model } & \multirow[t]{2}{*}{ Output } & \multicolumn{3}{|c|}{ Statistical Indicator } \\
\hline & & & & & & RMSE & MPE & $\mathrm{R}^{2}$ \\
\hline \multirow[t]{2}{*}{ [11] } & Ghardaïa & AMD & 2009-2010 & Brichambaut & HGSR & --- & $3.95 \%$ & --- \\
\hline & Bechar & AMD & $1972-1974$ & Brichambaut & HGSR & --- & $2.33 \%$ & --- \\
\hline [9] & Ghardaïa & Hourly & TD (2006) & ASHRAE & DNI & 19.20 & --- & 0.967 \\
\hline \multirow[t]{2}{*}{ [27] } & Ghardaïa & Hourly & TD (2006) & Lui \& Jordon & HGSR & 5.036 & $1.72 \%$ & --- \\
\hline & & MMD & 2006 & Garg & HGSR & --- & $1.94 \%$ & --- \\
\hline [30] & Bejaia & Daily & 2010 & Bahel & HGSR & 7.6889 & --- & --- \\
\hline [16] & Ghardaïa & MMD & --- & HDKR & IGSR & 0.0216 & $0.212 \%$ & --- \\
\hline \multirow[t]{2}{*}{ [34] } & Oran & MMD & 2009-2011 & Quadratic & HGSR & 0.0809 & 14.4408 & 0.769 \\
\hline & Bechar & MMD & 2009 & Cubic & HGSR & 0.1058 & -15.089 & 0.672 \\
\hline \multirow[t]{2}{*}{ [4] } & Constantine & MMD & 2010-2012 & Cubic & HDiff & 0.0617 & -12.220 & 0.960 \\
\hline & Adrar & MMD & 2011 & Quadratic & HDiff & 0.0456 & 16.8002 & 0.525 \\
\hline \multirow[t]{3}{*}{ [50] } & Adrar & MMD & --- & Rietveld & HGSR & 0.212 & 0.57 & --- \\
\hline & Bouzaréah & MMD & --- & McCulloch & HGSR & 0.225 & -2.47 & --- \\
\hline & Bouzaréah & MMD & --- & Lui\& Jordon & HDiff & 0.147 & -4.4 & --- \\
\hline \multirow[t]{3}{*}{ [37] } & Algiers & MMD & 2009-2011 & Several steps & DNI & 0.461 & 2.29 & 0.977 \\
\hline & Ghardaïa & MMD & 2005-2009 & Several steps & DNI & 0.491 & 0.153 & 0.773 \\
\hline & Tamanrasset & MMD & 1995-2009 & Several steps & DNI & 0.586 & 1.061 & 0.846 \\
\hline \multirow[t]{2}{*}{ [36] } & Adrar & MMD & --- & Quadratic & HGSR & 0.0293 & 0.0668 & --- \\
\hline & Beni Abbes & MMD & --- & Quadratic & HGSR & 0.0175 & 0.0346 & --- \\
\hline [49] & Ghardaïa & Hourly & 02/01/2009 & Capderou & HGSR & --- & --- & --- \\
\hline
\end{tabular}




\section{REMOTE SENSING AND SATELLITE IMAGES}

Unlike situ measurements, remote sensing measurements do not require stations on site. In this type of measurement, the acquisition of information is made remotely via satellite, radar or airplane. Remote sensing can be either passive when the sensor recovers the energy that is naturally available (i.e. satellite image) or active when the sensor produces its own energy (i.e. radar).

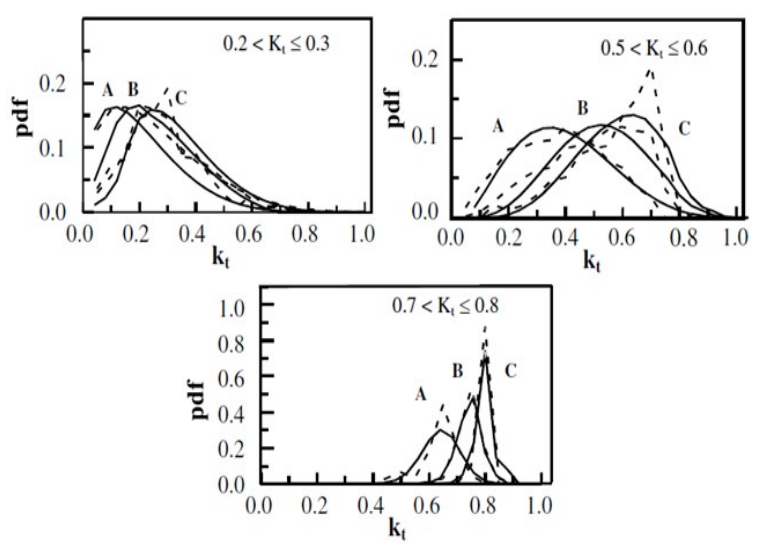

Fig. 16 Measured (- - -) and estimated (-) probability density functions of hourly clearness index for the regions of northern Algeria(with $A$ $5^{\circ}<h_{s} \leq 25^{\circ}$, B: $25^{\circ}<h_{s} \leq 50^{\circ}$ and C: $50^{\circ}<h_{s} \leq 90^{\circ}$ ) [54]:

The sensors receive and record the energy emitted or diffused by the target. Then, this energy will be processed and transformed into an image. For solar radiation, better accuracy is obtained from a combination of ground measurement and satellite imaging [9].

In Algeria, Several attempts have been made to identify solar potential via remote sensing. Preliminary work on $X$ was undertaken by Mefti et al. who have used the satellite based model SICIC, Solar irradiation from cloud image classification, to generate daily GSR. This model uses processed Meteosat images (Wefax and HR) and ground solar radiation measurements. The application of this model to Bouzaréah and Tamanrasset sites gave better results than that of GISTEL[10]. In [57], the author used the GISTEL model alone with HR and WefaxMeteosat images to estimate the ground level daily solar radiation. The comparison of the results with measurements recorded in Algiers gave discrepancies of $12 \%$ for HR images and $18 \%$ for Wefax images as indicated in figure 17.
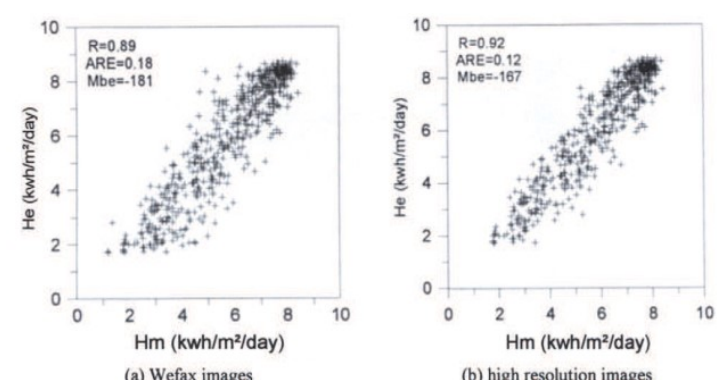

Fig. 17 Estimated $(\mathrm{He})$ versus measured $(\mathrm{Hm})$ daily GSR [57]

In the same vein, Boulifa et al. implemented a spectral analytical model based on atmospheric exchanges at ground level in order to evaluate the HGSR. The comparison of the results with ground measurements recorded at Adrar and Dar El Beida over the same period gave 0.87 and 0.92 correlation coefficients, respectively [58]. In [59], the authors implemented an analytical model using satellite image processing and the radiative transfer equation to estimate daily and hourly HGSR. The studied database consisted of clear-sky Meteosat three-hourly images recorded between 1986 and 1987 (figure 18). They stated that the correlation coefficient between the estimated and hourly ground measurements at Bouzaréah and Oran during the same period was about $90 \%$. In the same perspective, Tadj et al. used the GISTEL model (Gisementsolaire par télédétection) married with fuzzy logic to estimate the hourly HGSR data at Bouzaréah and Ghardaïa. The estimated data were compared to two-day ground level measurements for each site yielding an RMSE of about 0.21[60]. Figure 19 shows a comparison between the measured and simulated HGSR with and without FL method at Ghardaïa site.

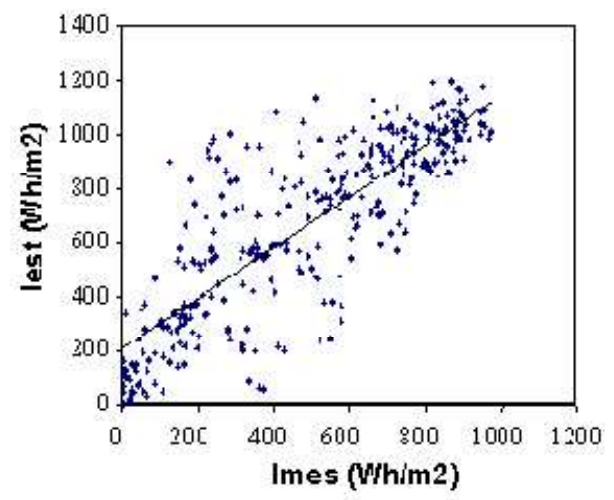

Fig. 18 Global irradiances estimated from Meteosat images versus the related ground measurements[59] 


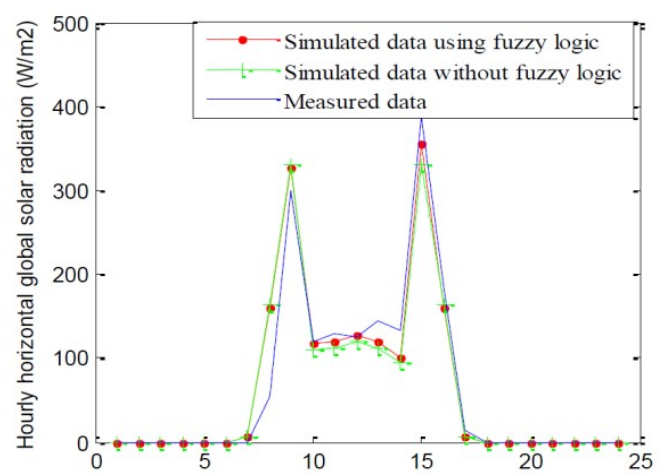

Fig. 19 Measured and simulated HGSR with and without FL method at Ghardaïa on 22 November 2012 [60]

Similarly, Meziani et al. have applied the GISTEL model to Meteosat images of $3 \mathrm{~km} x$ $3 \mathrm{~km}$ resolution, recorded every $15-\mathrm{min}$, to evaluate daily and hourly HGSR. The results were compared with measurements recorded in Tamanrasset during February 2011 (figure 19). The correlation coefficient was approximately 0.77 for the hourly values and 0.96 for daily values[61].

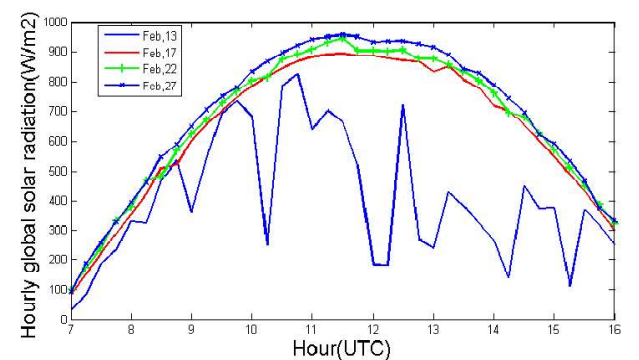

Fig. 20 Estimated GSR for the station of Tamanrasset on February 13, 17, 22 and 27 of 2011 in the visible channel VIS006[61]

\section{Solar maps}

There are a large number of published studies describing solar potential maps in Algeria. Such a trend is a natural consequence of solar evaluation and modeling that attempts to present a largescale overview. Thus, interpolation techniques are indispensable to allow the expansion of the information around the measurement point. Linear and nonlinear interpolation, principal component analysis and Kriging methods are all used in literature. In a pioneering study, Yaiche et al. generalized the annual mean daily sunshine duration parameter; measured at 64 Algerian stations between 2002 and 2011, to draw the sunshine duration map over all Algeria. Then, after having discretized the latitude and longitude characterizing Algeria to get 2137 points, they obtained the sunshine duration average according to the area color for each point. Consequently, they have calculated and drawn the map of HGSR. A comparison of the obtained results; at 20 points, to satellite data provided by Solar-Med-Atlas, Meteotest, and NASA produced mean relative errors $3.685 \%, 3.33 \%$ and $6.33 \%$, respectively. As a result, they found out that while the highest solar potential was around Djanet and Tamanrasset region, the lowest solar potential was around Skikda and Annaba region [11]. In [62], the authors presented the maps of GSR received on a horizontal plane, on an inclined plane at the latitude angle and on a vertical plane oriented east, west, south, south-east and south-west for Algeria for all types of sky as indicated in figure 21. They have used Brichambaut and Liu \& Jordan empirical models. As a result, they obtained a relative error between measured and estimated data of less than $7 \%$. In [63], the Solar Atlas of Algeria; based on new solar radiation estimation method, under all type of sky has been elaborated. Data measured between 1992 and 2002 of sunshine duration have been used to draw about thirty annual and monthly mean daily solar maps for different orientation and inclination.

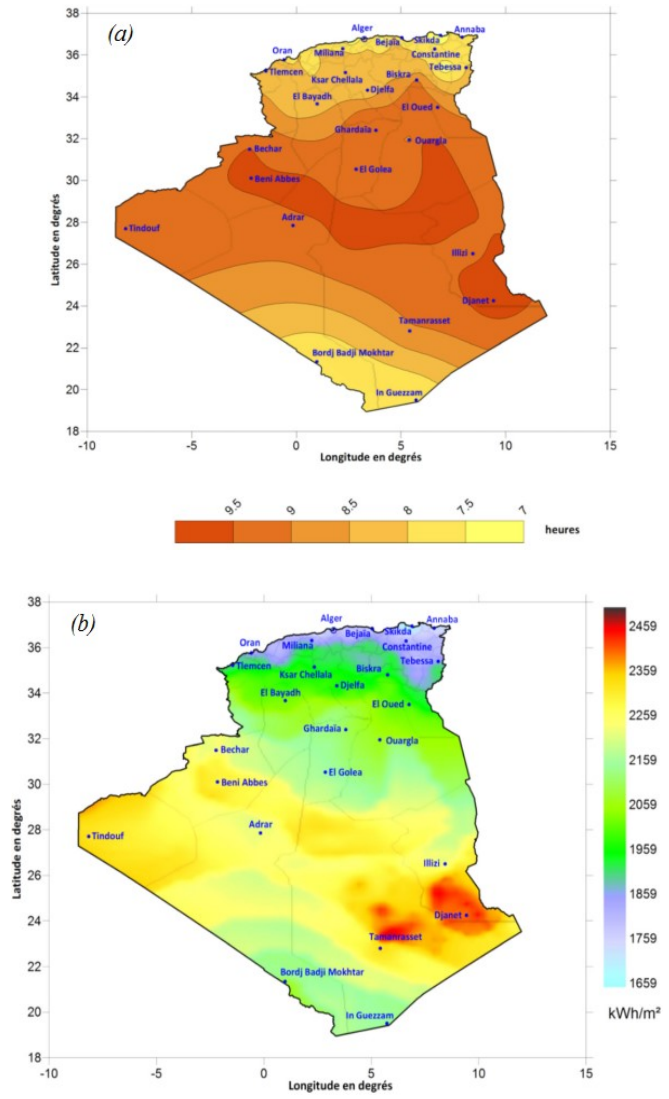

Fig. 21 (a) Measured annual mean daily sunshine duration (from 2002 to 2011). (b) Estimated annual HGSR [11] 
Similarly, Benmouiza has presented the map of mean monthly sunshine duration; using Surfer software with Kriging's interpolation method, for Algeria and for each month of the year. He has used hours of sunshine measured between 1992 and 2002 at 56 stations (mainly distributed in the north). The developed solar map divides Algeria into 6 energetic zones as illustrated in figure 22 that presents the monthly average sunshine maps of Algeria for four months of the year[26].

In their analysis of Algerian solar map, Abdeladim et al. used the Kriging method to perform the different interpolations via Surfer software. They took advantage of RETScreen software database to draw up Algerian maps of monthly and yearly GSR received on normal plane. This database includes data estimated by the NASA and ground measurement data. The relative errors between these two data; calculated for five sites, were acceptable[64]. In [65], the authors presented a solar mapping methodology based on the yearly average of HGSR for the whole Algerian territory as shown in figure 23. In [66], AngstromPrescott model has been used to estimate GSR from sunshine duration recorded at 64 Algerian stations. To validate the results, GSR measured at five Algerian sites (Algiers, Oran, Ghardaïa, Bechar and Tamanrasset) have been used. The authors obtained the lowest and the highest annual relative error for Tamanrasset and Oran, respectively. Then, they drew up the solar maps of daily GSR received on normal plane in December and July as illustrated in figure 24.

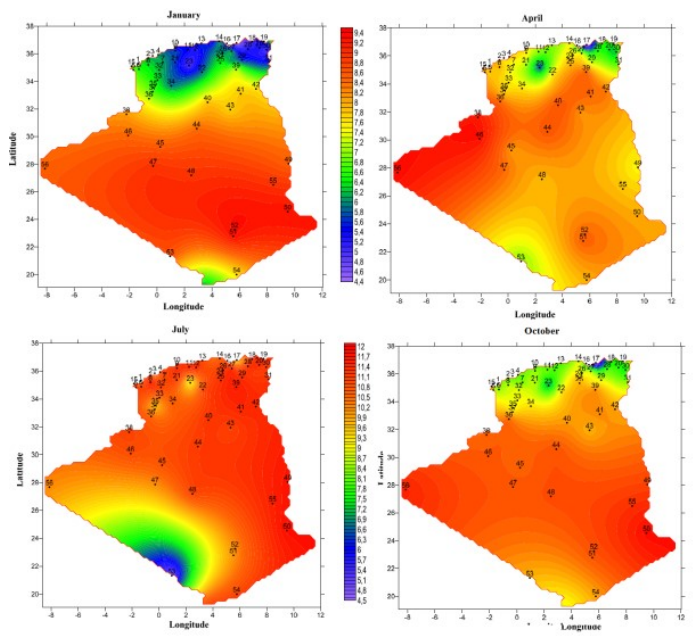

Fig. 22 Monthly average sunshine maps of Algeria for four months of the year [26]

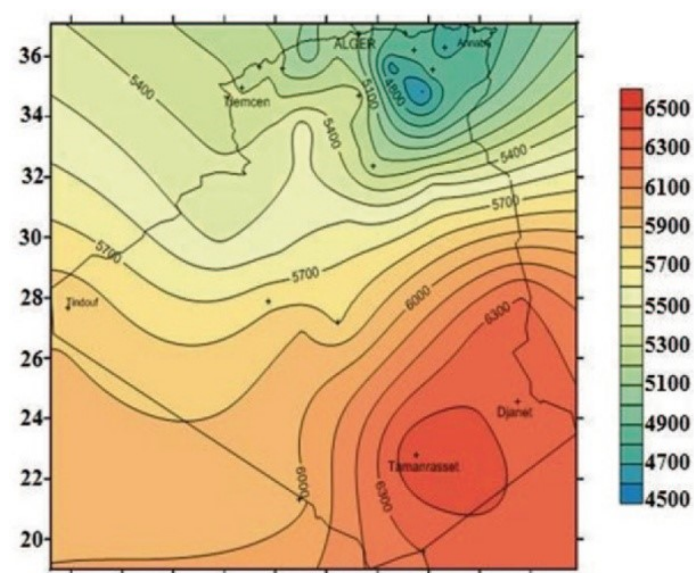

Fig. 23 Yearly average of HGSR[65]
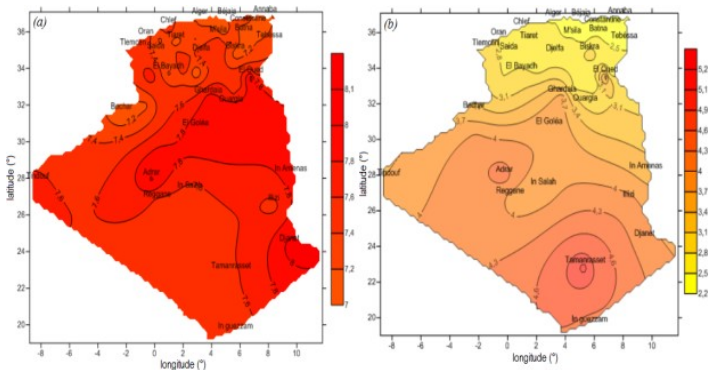

Fig. 24 Daily GSR received on normal plane in (a) Summer and (b)Winter[64]

In the same vein, Mellit et al. have presented up to 12 maps of monthly mean clearness indexes, corresponding to 2001 for Algeria; based on B-spline function interpolation[67]. Figure 25 presents the monthly mean clearness indexes, corresponding to 2001 for Algeria.
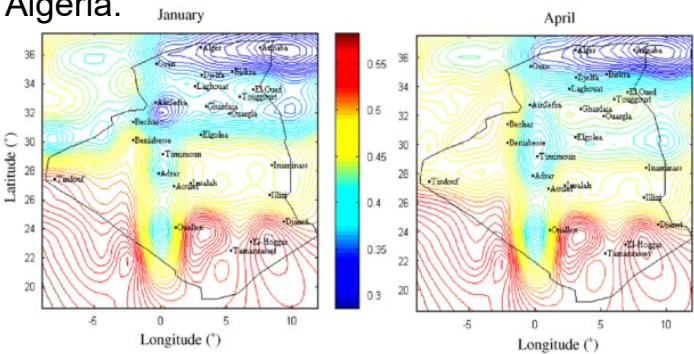

Fig. 25 Monthly mean clearness indexes, corresponding to 2001 for Algeria [67]

In one study by Youcef-Ettoumi et al., the authors applied beta probability distribution for solar radiation data smoothing. They have used daily sunshine durations recorded for at least 11 years at 33 Algerian stations. They demonstrated that daily sunshine duration and daily clearness indexes can be represented by a single beta distribution. However, for monthly clearness indexes, a linear combination of two beta distributions is the best representation. Then, the two 
parameters that characterize the resulting monthly beta probability distributions of daily sunshine duration were mapped as indicated in figure 26. These maps divided Algeria into 8 regions for each month [68]. In another work, the authors used Fourier analysis to analyze seasonal variations of monthly sunshine duration measured at 54 Algerian sites between 1992-1996[69]. They found that for latitudes more than $32^{\circ}$, these variations are represented by the fundamental component of Fourier series. For latitudes between $25^{\circ}$ and $32^{\circ}$, the first three harmonics were sufficient. Whereas in the south, for latitudes between $18^{\circ}$ and $25^{\circ}$, the six first harmonic components are required. Then, they gave the maps of the amplitude of the six first harmonic components and the phase of the first two ones, dividing Algeria into three regions.
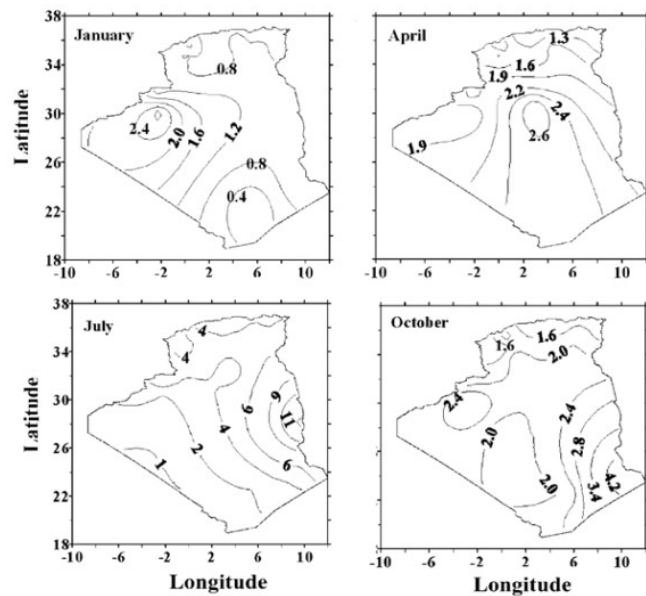

Fig. 26 Iso-coefficients $(p)$ for monthly beta probability distributions of daily sunshine duration for four months in Algeria [68].

In another major study, Mefti et al. have presented the map of GSR in Algeria, simulated under clear and average sky, for four seasons. Principal component analysis applied to sunshine fraction measured in 54 Algerian stations allowed the definition of five energy zones. The Angstrom relationship between monthly GSR and sunshine fraction has been established for each zone [70].

Messen has given the temporal and geographical evolution of solar radiation in Algeria from relative sunshine duration and atmosphere's transmissibility. Data recorded at 42 ONM stations between 1975 and 1984 has been used. The authors showed that the monthly solar radiation depends on the weather conditions while the average annual solar radiation depends on the astronomical factors. Then, they have established the mean daily cloud cover for January, annual average of solar radiation in Algeria and solar iso-radiation for January and July maps based on Brichambaut's relation as presented in figure 27 [71].
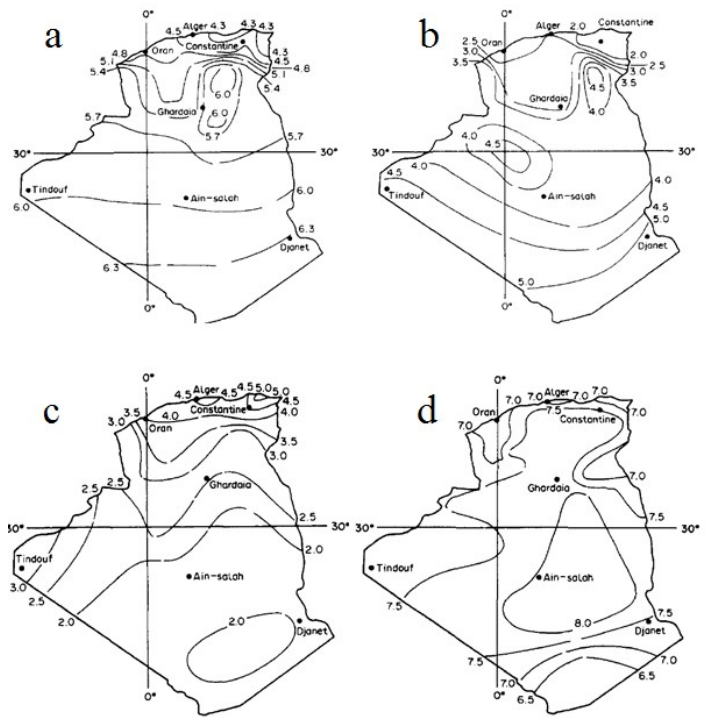

Fig. 27 (a) Annual average of solar radiation in Algeria; Solar iso-radiation map for January (b) and July (d); (kWh/m².day); (c) mean daily cloud cover (January) [71].

\section{Classification and Clustering of Solar Radiation Data}

Several methods for solar data classification techniques such as Bayesian network, decision tree, artificial neural networks and support vector machine are very useful on data classification and clustering [72]. In relation to the temporal fluctuation, the fractal dimension can also be used to classify solar radiation data according to the state of the sky. The fractal dimension varies from one for a clear sky to two for a variable sky[7375].

A large and growing body of literature has investigated in solar data classification such as the work of Djafer et al. who have used the wavelet transform and clearness index based method to determine clear sky and turbid days. GSR data recorded during four years (2005-2008) in Ghardaïa have been used, where the annual mean values of $K_{T}$ is 0.67 . It was found that the first method gave lower number of clear days in relation to the second one. The assessment of this difference; through estimating both GSR by lqbal $C$ model and turbidity parameters, showed that the first method is more efficient (Figure 28) [76].

Benmouiza et al. applied the fuzzy c-means algorithm to classify the hourly solar radiation data into three clusters. They used the lowest data obtained from the clustering processes 
to define the iso-probability curves. Hourly solar radiation data received on $32^{\circ}$ inclined plane in Ghardaïa during 2012 have been used. They demonstrated that using hourly data is better than using daily data for sizing standalone PV system [77]. The obtained results are shown in figure 29 that presents the clustered hourly IGSR using Fuzzy cmeans algorithm. In [78], the authors used the data clustering algorithm-Density-Based Spatial Clustering of Applications with Noise-to classify and to find out the noisy data of solar radiation time series. Contrary to the k-means and Fuzzy c-means techniques, this data mining is powerful in noisy data detection. 5123 hours of hourly GSR data, collected in Ghardaïa site during 2012, have been used. In [79], two clustering techniques; k-means and fuzzy c-means, for solar radiation measured in Ghardaïa have been presented in order to study its dynamic behavior and model its time series to find the models to be of use in PV systems applications.
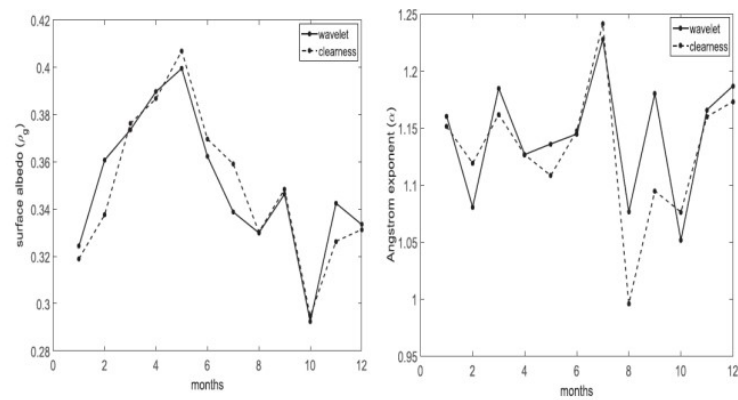

Fig. 28 Monthly average values of the surface albedo obtained from lqbal $\mathrm{C}$ model considering clear days obtained from the clearness index criteria and wavelet method (left). Monthly average values of the Angstrom exponent $\alpha$ using the same analysis (right) [76]

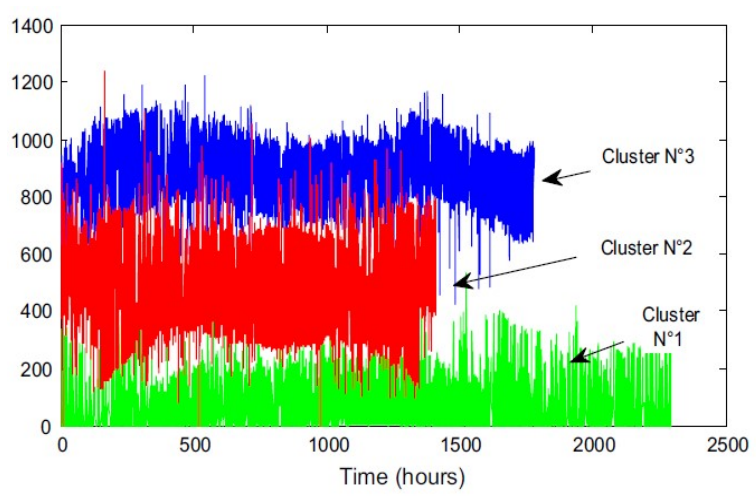

Fig. 29 Clustered hourly IGSR using Fuzzy cmeans algorithm[77]
Vindel et al. used fractal analysis to study the variability of daily HGSR and DNI in four worldwide sites. Hourly data of Tamanrasset site; between 2001 and 2011 from Baseline Surface Radiation Network, have been used. They found that the range of relative variability is higher in Tamanrasset due the presence of aerosols(clouds are very rare there) and this variability is more seen in global radiation than in direct radiation[80].

A detailed examination of GSR classification of GSR based on fractal dimension and clearness index has been presented by Harrouni presented. The studies have been carried out for Tahifet (Tamanrasset) and Imehrou (Illizi) using data of 1992 on an inclined plane have been used. In these investigations, the cumulative distribution function method has been used to determine the thresholds of fractal dimension. Then, three classes of sky have been determined (clear, partially cloudy and completely cloudy) as indicated in figure 30.The results showed that around $60 \%$ of days in both sites are in the first class and solar radiation in the first site is more fluctuating than in the second $[75,81,82]$.

Similarly and for the same sites (Tahifet and Imehrou), Maafi et al. used fractal modeling of solar radiations data; measured at a sampling time of 10-min over one year at Tahifet and Imehrou. The estimated daily fractal and the calculated daily clearness indexes have been used together to define a daily solar radiation classification. Then, three classes of sky (clear, partially cloudy and completely cloudy) have been identified as illustrated in figure 31. Later, they applied this model to analyze PV systems performances[83].

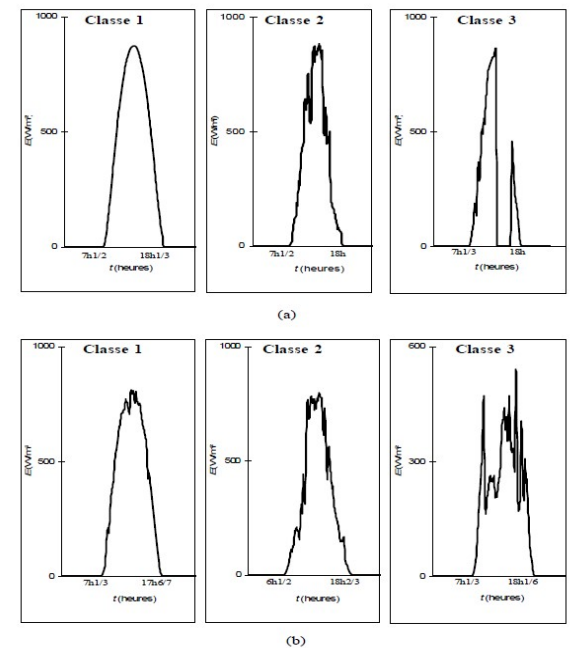

Fig. 30 Examplesof daily solar irradiance corresponding to the obtained three classes in (a) Tahifet and (b) Imehrou [82] 


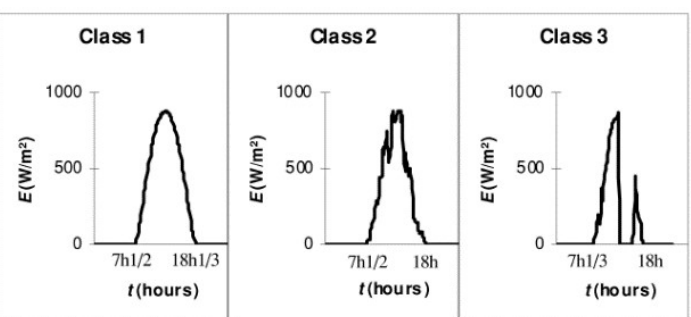

(a)

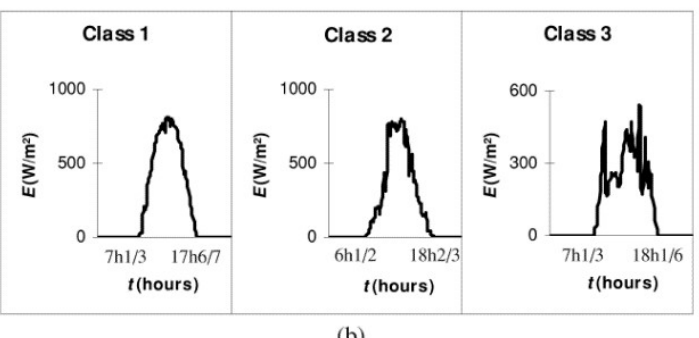

(b)

Fig. 31 Examples of daily solar irradiance corresponding to three classes of sky 1 (clear), 2 (partly cloudy) and 3 (completely cloudy) for (a) Tahifet and (b) Imehrou[83]

In a study that was set out to identify the different monochromatic solar radiation under clear sky, Koussa et al. used two spectral models. Daily data of thirty-eight clear sky days selected among measurements of seven parameters; recorded each 5-min during 3 years at Bouzaréah have been used. As results, it has been found that Bird model provide lower RMSE than Brine model for solar radiation components estimation. Moreover, according to turbidity factors and the precipitating water vapor, they classified the studied site as a rural site [84].
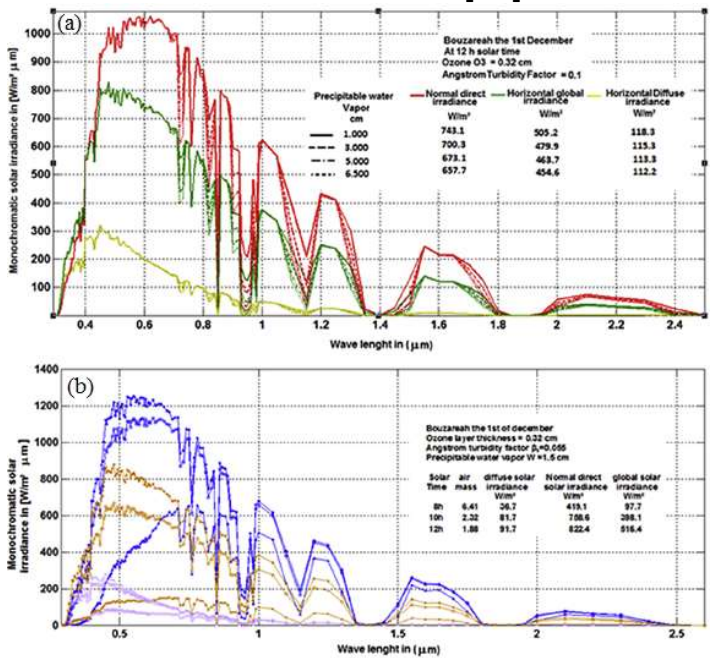

Fig. 32 Effect of Angstrom turbidity factor (a) and AM (b) on the monochromatic solar irradiances [84]

Mraoui et al. examined the effect of the angle of inclination on the amount of received solar energy, on the PV produced energy and on
PV system efficiency (figure 33). It has been found that the optimal tilt angle for monthly average minimum energy is close to the latitude $+23^{\circ}$ in Algiers and latitude $+10^{\circ}$ in Ghardaïa. For annual energy the optimal tilt angle was close to latitude for both of sites[85]. Obtained results are presented in Table 6 that indicates the maximizing tilt angle for Algiers and Ghardaïa.
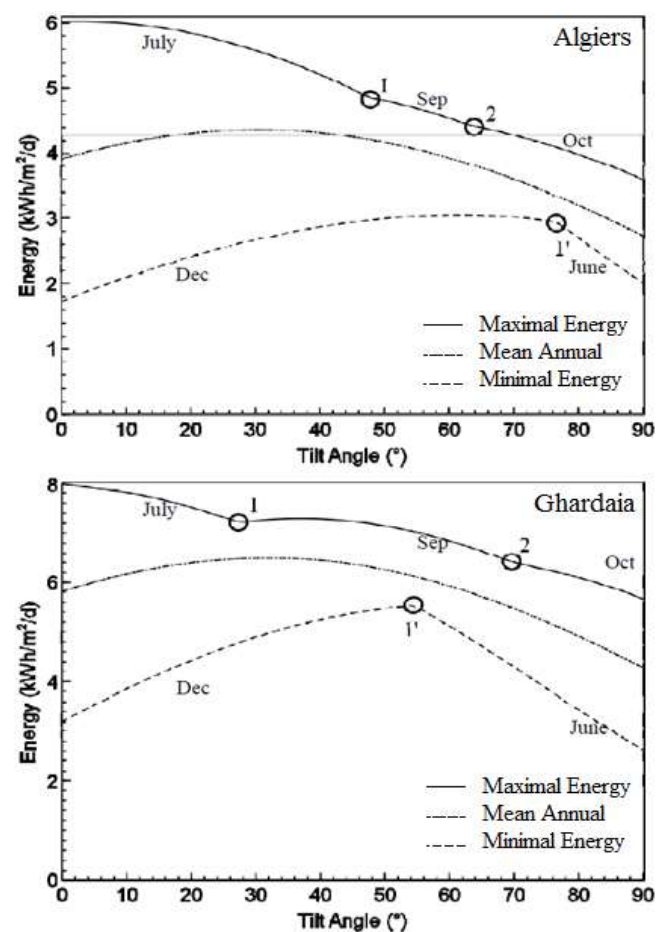

Fig. 33 Average energy according to tilt angle. The angle maximizing annual energy is close to latitude of Algiers and in Ghardaïa[85].

Table 6 Tilt angle maximizing produced electrical energy in Algiers (Alg) and Ghardaïa (Gha) [85]

\begin{tabular}{lcccccc}
\hline Month & \multicolumn{2}{c}{ Tsalides } & \multicolumn{2}{c}{ El-Kassaby } & \multicolumn{2}{c}{ Ref. [85] } \\
\cline { 2 - 7 } & Alg & Gha & Alg & Gha & Alg & Gha \\
\hline January & 52 & 64 & 64 & 60 & 59 & 61 \\
February & 52 & 55 & 55 & 51 & 51 & 53 \\
March & 57 & 41 & 41 & 36 & 39 & 37 \\
April & 55 & 21 & 21 & 17 & 22 & 15 \\
May & 58 & 4 & 4 & 0 & 8 & 0 \\
June & 61 & 0 & 0 & 0 & 1 & 0 \\
July & 61 & 0 & 0 & 0 & 5 & 0 \\
August & 59 & 14 & 14 & 10 & 16 & 8 \\
September & 59 & 33 & 33 & 29 & 32 & 29 \\
October & 59 & 51 & 51 & 46 & 47 & 48 \\
November & 58 & 62 & 62 & 58 & 55 & 59 \\
December & 52 & 66 & 66 & 62 & 62 & 62 \\
$\quad$ MAE & 26.6 & 3.25 & 3.33 & 0.92 & & \\
\hline
\end{tabular}

\section{CONCLUSION}

A review on the estimation and prediction of solar radiation in Algeria since 1987 has been carried out in the current study. The geostrategic location of Algeria; at the center of the world and solar belt, as well as the world renewable energy growing tendency, favor this country especially in terms of solar 
energy. The wide applications of solar energy, PV and thermal system design, architecture, agriculture, etc. require good knowledge of solar radiation data. In addition, the accuracy of these data is directly related to the amount of solar energy that can be integrated in the national electricity grid since it allows better power regulation. However, the unavailability of these data in this vast country due to technical and economic barriers has forced the researchers to find and develop several other alternatives. In this context, the maximum number of studies made on determining solar radiation components (global, direct, and diffuse) on horizontal, normal and inclined plane and for different time step in Algeria is presented.

Different studies made on solar radiation estimation are presented. Semi-empirical and parametric, stochastic as well as satellite imagery studies have been presented. A wide range of suitable parametric and semiempirical models based on meteorological and geographical parameters-sunshine duration, air temperature, relative humidity, atmospheric pressure, latitude, longitude, altitude, etc.-have been used. On the other hand, a few studies have been found forsatellite images modeling.

Therefore, in the case of Algeria, it can be concluded that semi-empirical models have been widely employed in solar radiation estimation. This may guide the future trends towards the less used hybrid models. It has been observed that among 75 National Meteorological Office (ONM) stations and some other individual stations, only 28 Algerian sites have been studied. Moreover, it has been found that the sites of Ghardaïa, Algiers and Tamanrasset, located in the three zones of Algeria (central, northern and southern) are the most studied sites. This may be due to the two radiometric stations installed in "Renewable Energy Development Center" at Algiers and its research unit "Unit of Applied Research in Renewable Energy" at Ghardaïa and/or the availability of data from there.

\section{APPENDICES}

Appendix A: The different models used for the estimation of solar radiation.

Hereafter are carried out the different models, used in the reviewed papers, to estimate solar radiation over Algeria. Other models e.g. Modified Iqbal Model C, Metstat, and CSRare variants of lqbal $C$ model.
Table A Different models used in the reviewed

\begin{tabular}{|c|c|c|}
\hline Model & $\begin{array}{c}\text { Formulation } \\
\end{array}$ & Used in \\
\hline Abdalla & $G_{H} / G_{0}=a+b \sigma+c T+d R_{H}$ & {$[17,30,39]$} \\
\hline Allen1 & $G_{H} / G_{0}=a T^{b}$ & {$[34]$} \\
\hline Allen2 & $\begin{array}{l}\frac{G_{H}}{G_{0}} \\
=0.17 \sqrt{T\left(\frac{293-0.0065 A l t}{293}\right)^{5.26}}\end{array}$ & [34] \\
\hline $\begin{array}{l}\text { Almorox } \\
\text { (Exponential) }\end{array}$ & $G_{H} / G_{0}=a+b e^{\sigma}$ & {$[17,42,43]$} \\
\hline $\begin{array}{l}\text { Ampratwum } \\
\text { (Logarithmic) }\end{array}$ & $G_{H} / G_{0}=a+b \log \sigma$ & $\begin{array}{l}{[4,17,34,36,40,4} \\
2,43]\end{array}$ \\
\hline $\begin{array}{l}\text { Angstrom- } \\
\text { Prescott } \\
\text { (linear) }\end{array}$ & $G_{H} / G_{0}=a+b \sigma$ & $\begin{array}{l}{[17,26,27,30,39,} \\
40,55,66]\end{array}$ \\
\hline ASHRAE & $\begin{array}{l}B_{H} \\
=A_{a s h} \cos \theta_{Z} \exp \left[-P B_{a s h} / P_{0} \cos \theta\right.\end{array}$ & [9] \\
\hline $\begin{array}{l}\text { Atwater \& } \\
\text { Ball }\end{array}$ & $\begin{array}{l}\begin{array}{l}G_{H} \\
=\end{array} I_{s c} \cos \theta_{Z}\left[\left(\tau_{m}-\alpha_{w}\right) \tau_{a} /(1-0.0\right. \\
\quad B_{N}=I_{S c} \cos \theta_{Z}\left(\tau_{m}-\alpha_{w}\right) \tau_{a}\end{array}$ & {$[9,27,29]$} \\
\hline $\begin{array}{l}\text { Bahel } \\
\text { (Cubic) }\end{array}$ & $G_{H} / G_{0}=a+b \sigma+c \sigma^{2}+d \sigma^{3}$ & $\begin{array}{l}{[4,30,34,36,39,4} \\
0]\end{array}$ \\
\hline Barbaro & $\begin{array}{c}G_{H}= \\
{\left[K S^{1.21}+362.6\left(\sinh _{n}\right)^{1.91}+\right.} \\
\left.10\left(\sinh _{n}\right)^{3}\right] / 24 \\
\end{array}$ & {$[55]$} \\
\hline $\begin{array}{l}\text { Bird } \\
\& \text { Hulstrom }\end{array}$ & $B_{H}=0.9662 I_{s c} \tau_{T} \cos \theta_{Z}$ & {$[9,26,29]$} \\
\hline Brichambaut & $\begin{array}{c}B_{H}=125 c \sinh ^{0.4} \\
D_{H}=I_{0} \exp [-a /(b \sin (h+1))]\end{array}$ & {$[21,70]$} \\
\hline $\begin{array}{l}\text { Bristow \& } \\
\text { Campbell }\end{array}$ & $G_{H} / G_{0}=a\left[1-\exp \left(-b \Delta T^{0.5}\right)\right]$ & [7] \\
\hline Capderou & $\begin{array}{l}B_{H} \\
=I_{S c} \sinh \exp \left[-T_{L} /(0.9+9.4 / 0 .\right. \\
\\
D_{H} \\
\quad=I_{S c} \exp [-1+1.06 \log \sinh \\
\left.\quad+a-\sqrt{a^{2}+b^{2}}\right]\end{array}$ & $\begin{array}{l}{[22,23,25,48,52,} \\
54]\end{array}$ \\
\hline Chen & $G_{H} / G_{0}=a+b \log \left(T_{\max }-T_{\min }\right)$ & {$[7,34]$} \\
\hline $\begin{array}{l}\text { CollaresParei } \\
\text { ra\&Rabl }\end{array}$ & $\begin{array}{l}\overline{\overline{G_{H}}} \\
=\overline{G_{H}} \frac{\pi}{24}(x \\
+y \cos \omega) \frac{\cos \omega-\cos \omega_{s}}{\sin \omega_{s}-\left(\frac{\pi \omega_{s}}{180}\right) \cos \omega_{s}}\end{array}$ & {$[31,32,37,44]$} \\
\hline Coppolino & $G=0.002167 S^{0.5}\left(\sinh _{n}\right)^{1.15}$ & {$[27]$} \\
\hline Cubic $\left(K_{T}\right)$ & $\begin{array}{r}D_{H} / G_{H}=a+b K_{T}+c K_{T}^{2} \\
+d K_{T}^{3}\end{array}$ & {$[4,33,50]$} \\
\hline $\begin{array}{l}\text { Daneshyar- } \\
\text { Paltridge- } \\
\text { Proctor }\end{array}$ & $\begin{array}{l}B \\
=950.2[1 \\
-\exp \left(-0.075\left(90^{\circ}\right.\right. \\
\left.\left.\left.-\theta_{Z}\right)\right)\right] \cos \theta_{Z}\end{array}$ & [9] \\
\hline $\begin{array}{l}\text { Davies \& } \\
\text { Hay }\end{array}$ & $\begin{array}{c}B_{H}=I_{S c} \cos \theta_{Z}\left(\tau_{o} \tau_{r}-\alpha_{w}\right) \tau_{a} \\
D_{H}=D_{r}+D_{a}+D_{m}\end{array}$ & {$[9,26,29]$} \\
\hline $\begin{array}{l}\text { Donatelli\& } \\
\text { Campbell }\end{array}$ & $G_{H} / G_{0}=a\left[1-\exp \left(-b f(\bar{T})\left(T_{m a}\right.\right.\right.$ & ${ }_{x}^{[7]}$ \\
\hline Erbs & 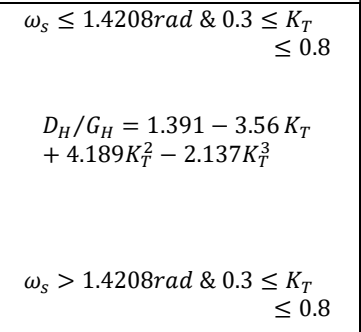 & {$[45,46,50]$} \\
\hline
\end{tabular}


ALGERIAN JOURNAL OF SIGNALS AND SYSTEMS (AJSS)

\begin{tabular}{|c|c|c|}
\hline & $\begin{array}{l}D_{H} / G_{H}=1.311-3.022 K_{T} \\
+3.427 K_{T}^{2}-1.821 K_{T}^{3}\end{array}$ & \\
\hline Exponent & $G_{H} / G_{0}=a+\sigma^{b}$ & {$[34,36]$} \\
\hline Exponential & $G_{H} / G_{0}=a e^{b \sigma}$ & {$[4,34,36,40]$} \\
\hline $\begin{array}{l}\text { Exponential } \\
\left(K_{T}\right)\end{array}$ & $D_{H} / G_{H}=a e^{b K_{T}}$ & [4] \\
\hline Fu \& Rich & $B=I_{0} \cos \theta_{Z} \tau_{\text {bulk }}^{m_{f}}$ & [9] \\
\hline Garg & $G_{H} / G_{0}=a+b \sigma+c w$ & {$[27,50]$} \\
\hline Gaussian & $\begin{array}{l}\overline{\overline{G_{H}}} \\
=\overline{G_{H}}\left[a+\frac{b}{\sigma^{\prime} \sqrt{2 \pi}}\right. \\
\left.+\exp \left(-\frac{2(t-12)^{2}}{\sigma^{\prime 2}}\right)\right]\end{array}$ & [44] \\
\hline $\begin{array}{l}\text { Glover \& } \\
\text { McCulloch }\end{array}$ & $G_{H} / G_{0}=0.29 \cos \varphi+0.52 \sigma$ & {$[50]$} \\
\hline Goodin & $G_{H} / G_{0}=a\left[1-\exp \left(-b\left(T_{\max }-\right.\right.\right.$ & [7] \\
\hline Gueymard & $D_{i}=D_{H}\left[\left(1-N_{g}\right) R_{d 0}+N_{g} R_{d 1}\right]$ & {$[18,19]$} \\
\hline HA & $G H=R I_{s c}\left[a \sinh +b \sin ^{2} h\right]$ & [44] \\
\hline Hargreaves & $G_{H} / G_{0}=a+b \Delta T^{0.5}$ & {$[7,17,34]$} \\
\hline $\begin{array}{l}\text { Hargreaves \& } \\
\text { Samani }\end{array}$ & $G_{H} / G_{0}=a \Delta T^{0.5}$ & {$[7]$} \\
\hline HDKR & $\begin{array}{l}G_{i} \\
=\left(B_{H}+A_{i} D_{H}\right) R_{b} \\
+G_{H} \rho \frac{1-\cos \beta}{2} \\
+D_{H}\left[\left(1-A_{i}\right) \frac{1+\cos \beta}{2}[1\right. \\
\left.\left.+\sin ^{3} \frac{\beta}{2}\right]\right]\end{array}$ & {$[16,18,19]$} \\
\hline Heliostat-1 & $B_{H}=I_{0} \cos \theta_{Z} \exp \left(-m_{\text {air }} \sigma^{\prime} T_{L}\right)$ & {$[9]$} \\
\hline HLJ & $B=I_{0} \cos \theta_{Z} \tau_{D}$ & [9] \\
\hline Hoyt & $\begin{array}{l}B_{H} \\
=I_{s c} \tau_{a} \tau_{r} \cos \theta_{Z}\left(1-\sum_{i=1}^{5} a_{i}\right)\end{array}$ & [9] \\
\hline $\begin{array}{l}\text { Iqbal Model } \\
\text { C }\end{array}$ & $B_{H}=0.9751 I_{s c} \tau_{T} \cos \theta_{Z}$ & [9] \\
\hline Jain & $\begin{array}{l}\overline{\overline{G_{H}}} \\
=\overline{G_{H}}\left[\left(1 /\left(0.2 S_{0}+0.378\right) \sqrt{2 \pi}\right) \operatorname{ex}\right.\end{array}$ & {$[50]$} \\
\hline Kumar & $\begin{array}{l}B \\
=0.56 I_{0}\left[\exp \left(-0.65 m_{\text {air }}\right)\right. \\
\left.+\exp \left(-0.095 m_{\text {air }}\right)\right]\end{array}$ & [9] \\
\hline Klucher & $\begin{array}{l}D_{i} \\
=D_{H} \frac{1-\cos \beta}{2}[1 \\
\left.+f_{k} \sin ^{3} \frac{\beta}{2}\right] \\
\left.+f_{k} \cos ^{2} \theta_{i} \sin ^{3} \theta_{Z}\right]\end{array}$ & {$[16,28,84]$} \\
\hline $\begin{array}{l}\text { Lacis \& } \\
\text { Hansen }\end{array}$ & $\begin{array}{l}G_{H} \\
=I_{s c} \cos \theta_{Z}\left[\frac{0.647-\rho_{s}^{\prime}-\alpha_{o}}{1-0.0685 \rho}\right. \\
\left.+0.353-\alpha_{w}\right]\end{array}$ & {$[9,22,26,27,29]$} \\
\hline Laue & $\begin{array}{l}B \\
=I_{0}\left[(1-0.14 \varphi) 0.7^{m_{\text {air }}^{0.678}}\right. \\
+0.14 \varphi]\end{array}$ & [9] \\
\hline $\begin{array}{l}\text { Lieu \& } \\
\text { Jordan }\end{array}$ & $\begin{array}{l}G_{H} \\
=B_{H} R_{b}+D_{H}\left(\frac{1+\cos \beta}{2}\right) \\
+\rho\left(\frac{1-\cos \beta}{2}\right)\end{array}$ & $\begin{array}{l}{[16,18,19,21-} \\
23,25,27,28,31, \\
32,41]\end{array}$ \\
\hline $\begin{array}{l}\text { Lieu \& } \\
\text { Jordan }\end{array}$ & $\begin{array}{l}\overline{\overline{D_{H}}} \\
=\overline{D_{H}} \frac{\pi}{24} \frac{\cos \omega-\cos \omega_{s}}{\sin \omega_{s}-\left(\frac{\pi \omega_{s}}{180}\right) \cos \omega_{s}}\end{array}$ & [50] \\
\hline Linear $\left(K_{T}\right)$ & $D_{H} / G_{H}=a+b K_{T}$ & [4] \\
\hline $\begin{array}{l}\text { Logarithmic } \\
\left(K_{T}\right)\end{array}$ & $D_{H} / G_{H}=a+b \log K_{T}$ & [4] \\
\hline Ma-Iqbal & $\begin{array}{l}G_{i} \\
=G_{H}\left[K_{T} R_{b}+\left(1-K_{T}\right) \cos ^{2} \frac{\beta}{2}\right]\end{array}$ & {$[18,19]$} \\
\hline Meinel & $B=I_{0} \cos \theta_{Z} 0.7^{m_{\text {air }}^{0.678}}$ & [9] \\
\hline Muneer & $D_{i}=D_{H}\left[T_{M}\left(1-F_{M}\right)+F_{M} R_{b}\right]$ & {$[18,19]$} \\
\hline
\end{tabular}

\begin{tabular}{|c|c|c|}
\hline Newland & $G_{H} / G_{0}=a+b \sigma+\log \sigma$ & {$[30,39]$} \\
\hline $\begin{array}{l}\text { Ogelman } \\
\text { (Quadratic) }\end{array}$ & $G_{H} / G_{0}=a+b \sigma+c \sigma^{2}$ & $\begin{array}{l}{[4,17,34,36,40,4} \\
2]\end{array}$ \\
\hline $\begin{array}{l}\text { Ojosu\&Kom } \\
\text { olafe }\end{array}$ & $\begin{aligned} G_{H} / G_{0}= & a+b \sigma+c\left(T_{\min } / T_{\max }\right)+ \\
& d\left(R_{H \min } / R_{H \max }\right)\end{aligned}$ & {$[17]$} \\
\hline Page & $D_{H} / G_{H}=1-1.13 G_{H} / G_{0}$ & {$[41,50]$} \\
\hline Perez & $\begin{array}{l}D_{i} \\
=D_{H}\left[\frac{1+\cos \beta}{2}\left[1-F_{1}\right]+F_{1} \frac{A}{B}\right. \\
\left.+F_{2} \sin \beta\right]\end{array}$ & {$[16,28,31,32]$} \\
\hline $\begin{array}{l}\text { Quadratic } \\
\left(\mathrm{K}_{\mathrm{T}}\right)\end{array}$ & $D_{H} / G_{H}=a+b K_{T}+c K_{T}^{2}$ & [4] \\
\hline Rietveld & $G_{H} / G_{0}=0.18+0.62 \sigma$ & {$[50]$} \\
\hline R. Sun & $\begin{array}{l}B_{H} \\
=I_{S C} \sinh \exp \left(-0.8662 T_{L} m_{\text {air }} \delta_{R}\right)\end{array}$ & {$[25,52]$} \\
\hline $\begin{array}{l}\text { Temps \& } \\
\text { Coulson }\end{array}$ & $\begin{array}{l}D_{i} \\
=D_{H} \frac{1-\cos \beta}{2}\left[1+\sin ^{3} \frac{\beta}{2}\right] \\
\left.+\cos ^{2} \theta_{i} \sin ^{3} \theta_{Z}\right]\end{array}$ & {$[19,26,28]$} \\
\hline Weiss & $\begin{array}{c}G_{H} / G_{0}=a\left[1-\exp \left(-b\left(T_{\max ^{-}}\right.\right.\right. \\
\left.\left.\left.T_{\min }\right)^{c}\right)\right]\end{array}$ & [7] \\
\hline Willmot & $D_{i}=D_{H}\left[\frac{B_{N}}{I_{0}} R_{b}+C_{\beta}\left(1-\frac{B_{N}}{I_{0}}\right)\right]$ & {$[18,19]$} \\
\hline Other1 & $G_{H} / G_{0}=K \sigma^{0.63}\left(\sinh _{n}\right)^{-0.19}$ & [56] \\
\hline Other2 & $G_{H} / G_{0}=a+b \sigma+c R_{H}$ & [40] \\
\hline Other3 & $G_{H} / G_{0}=a+b \sigma+c\left(T_{\min } / T_{\max }\right)$ & [40] \\
\hline Other4 & $\begin{array}{c}G_{H} / G_{0}=a+b \sigma+c\left(T_{\min } / T_{\max }\right)+ \\
d R_{H}\end{array}$ & [40] \\
\hline
\end{tabular}

\section{Appendix B: Statistical Indicators}

Statistical indicators are used to evaluate the differences between estimated or predicted data and measured data, and to evaluate the accuracy and improve the performances of the models used. The most commonly used parameters are RMSE, MBE and $R^{2}$. Other parameters include $S D$ (standard deviation), $d$ (index of agreement), SCR (sum of squared errors), MSE (mean square error), $t_{\text {sta }}$ (t statistic), NSE (Nash-Sutcliffe equation) and $e \%$ (error in percent).

\section{a) RMSE (root-mean-square error)}

The RMSE measures the variation of the calculated value around the measured one. This parameter is always positive; its ideal value is zero. Its normalized value $n R M S E$ is also used.

\section{b) $\quad M B E$ (mean bias error)}

The mean distortion error shows the mean deviation of the calculated value around the measured value. Its normalized value $n M B E$ and absolute MABE are also used.

\section{c) MPE (mean percentage error)}

The MPE shows the percentage deviation of the measured and calculated values. Its absolute value is also defined asMAPE.

d) Coefficient of determination $\left(R^{2}\right)$ The coefficient of correlationrepresents the proportion of variability of the measured data.This parameter varies between 0 and 1 . The ideal value is one.

The error is defined as the difference between the measured value and the 
calculated value $\left(E R R=V_{m^{-}} \quad V c\right)$. The following table gives the famous statistical indicators.

Table B Summary of statistical indicators

\begin{tabular}{|c|c|c|c|}
\hline & $M P E$ & & $M A P E$ \\
\hline MPE & $\begin{array}{l}=100 * \frac{1}{n} \\
* \sum_{i=1}^{n} \frac{E R R}{V_{m}}\end{array}$ & MAPE & $\begin{array}{l}=100 * \frac{1}{n} \\
* \sum_{i=1}^{n}\left|\frac{E R R}{V_{m}}\right|\end{array}$ \\
\hline MBE & $\begin{array}{l}M B E \\
=\frac{1}{n} * \sum_{i=1}^{n} E R R \\
n M A B E \\
M A B E\end{array}$ & MABE & $\begin{array}{l}M A \overline{B E} \\
=\frac{1}{n} * \sum_{i=1}^{n}|E R R| \\
R^{2} \\
=1\end{array}$ \\
\hline nMABE & $\begin{array}{l}=\frac{1}{\frac{1}{n} * \sum_{i=1}^{n} V_{m}} \\
* 100\end{array}$ & $\mathbf{R}^{2}$ & $-\frac{\sum_{i=1}^{n} E R R^{2}}{\sum_{i=1}^{n}\left(V_{m}-\overline{V_{m}}\right)^{2}}$ \\
\hline
\end{tabular}

RMSE $=\sqrt{\frac{\sum_{i=1}^{n} E R R^{2}}{n}} \quad$ nRMSE $=100 * \frac{R M S E}{\frac{1}{n} * \sum_{i=1}^{n} V_{m}}$

Table C Geographical characteristics of the sudied sites.

\begin{tabular}{|c|c|c|c|c|c|c|c|c|c|}
\hline \multicolumn{2}{|c|}{ STATIONS } & $\begin{array}{l}\text { Latitude } \\
\text { (N) }\end{array}$ & $\begin{array}{l}\text { Longitude } \\
\text { (E/W) }\end{array}$ & $\begin{array}{c}\text { Altitude } \\
\text { (m) }\end{array}$ & \multicolumn{2}{|l|}{ STATIONS } & $\begin{array}{l}\text { Latitude } \\
\text { (N) }\end{array}$ & $\begin{array}{l}\text { Longitude } \\
\text { (E/W) }\end{array}$ & $\begin{array}{c}\text { Altitude } \\
\text { (m) }\end{array}$ \\
\hline \multicolumn{2}{|l|}{ Adrar } & $27^{\circ} 49$ & $0^{\circ} 11 \mathrm{~W}$ & 279 & \multicolumn{2}{|l|}{ Illizi Imehrou } & $26^{\circ}$ & $8^{\circ} 50 \mathrm{E}$ & 600 \\
\hline \multicolumn{2}{|c|}{ AïnBessem } & $36^{\circ} 19$ & $3^{\circ} 32 \mathrm{E}$ & 748 & \multicolumn{2}{|l|}{ InGuezzam } & $19^{\circ} 34$ & $5^{\circ} 46 \mathrm{E}$ & 401 \\
\hline \multicolumn{2}{|c|}{ BatnaA.Skhouna } & $35^{\circ} 43$ & $6^{\circ} 21 \mathrm{E}$ & 827 & \multicolumn{2}{|l|}{ KsarChellala } & $35^{\circ} 10$ & $2^{\circ} 19 \mathrm{E}$ & 800 \\
\hline \multicolumn{2}{|c|}{ Bechar } & $31^{\circ} 38$ & $2^{\circ} 15 \mathrm{~W}$ & 807 & \multicolumn{2}{|l|}{ Mascara ghriss } & $35^{\circ} 13$ & $0^{\circ} 09 \mathrm{E}$ & 513 \\
\hline \multicolumn{2}{|c|}{ Bejaïa aéroport } & $36^{\circ} 43$ & $5^{\circ} 04 \mathrm{E}$ & 2 & \multicolumn{2}{|l|}{ Mostaganem } & $35^{\circ} 53$ & $0^{\circ} 07 \mathrm{E}$ & 137 \\
\hline \multicolumn{2}{|c|}{ Béni Abbes } & $30^{\circ} 08$ & $2^{\circ} 10 \mathrm{~W}$ & 499 & \multicolumn{2}{|l|}{ Oran sénia } & $35^{\circ} 38$ & $0^{\circ} 36 \mathrm{~W}$ & 90 \\
\hline \multicolumn{2}{|c|}{ Blida Univ. } & 36)16 & $2^{\circ} 28 \mathrm{E}$ & 120 & \multicolumn{2}{|l|}{ Ouargla } & $31^{\circ} 55$ & $5^{\circ} 24 \mathrm{E}$ & 139 \\
\hline \multicolumn{2}{|c|}{ Boumerdes } & $36^{\circ} 46$ & $3^{\circ} 42 \mathrm{E}$ & --- & \multicolumn{2}{|l|}{ Sétif aïnSfiha } & $36^{\circ} 11$ & $5^{\circ} 15 \mathrm{E}$ & 1033 \\
\hline \multicolumn{2}{|c|}{ Bouzaréah CDER } & $36^{\circ} 47$ & $3^{\circ} \mathrm{E}$ & 345 & \multicolumn{2}{|c|}{ Tamanrasset Tahifet } & $22^{\circ} 58$ & $6^{\circ}$ & 1389 \\
\hline \multicolumn{2}{|c|}{ Constantine } & $36^{\circ} 17$ & $6^{\circ} 37 \mathrm{E}$ & 694 & \multicolumn{2}{|c|}{ Tamanrasset ville } & $22^{\circ} 48$ & $5^{\circ} 31 \mathrm{E}$ & 1377 \\
\hline \multicolumn{2}{|c|}{ DarEIBeïda } & $36^{\circ} 41$ & $3^{\circ} 13 \mathrm{E}$ & 25 & \multicolumn{2}{|l|}{ Tébessa } & $35^{\circ} 25$ & $8^{\circ} 07 \mathrm{E}$ & 820 \\
\hline \multicolumn{2}{|c|}{ DellyBrahim } & $36^{\circ} 44$ & $2^{\circ} 58 \mathrm{E}$ & 190 & \multicolumn{2}{|l|}{ Tindouf } & $27^{\circ} 42$ & $8^{\circ} 10 \mathrm{~W}$ & 443 \\
\hline \multicolumn{2}{|l|}{ Djelfa } & $34^{\circ} 20$ & $3^{\circ} 23 \mathrm{E}$ & 1180 & \multicolumn{2}{|l|}{ Tlemcen SafSaf } & $34^{\circ} 57$ & $1^{\circ} 17 \mathrm{~W}$ & 592 \\
\hline \multicolumn{2}{|c|}{ Ghardaïa URAER } & $32^{\circ} 36$ & $3^{\circ} 48 \mathrm{E}$ & 450 & \multicolumn{2}{|l|}{ Tlemcen zenata } & $35^{\circ} 01$ & $1^{\circ} 27 \mathrm{~W}$ & 210 \\
\hline $\begin{array}{l}\text {, c, d } \\
h, B_{\text {ash }}\end{array}$ & \multicolumn{4}{|c|}{$\begin{array}{l}\text { empirical values } \\
\text { the apparent solar-radiation constant and the } \\
\text { atmospheric extinction coefficient } \\
\text { anisotropy index } \\
\text { absorption coefficients } \\
\text { Altitude } \\
\text { direct, diffuse, extraterrestrial and GSR on } \\
\text { horizontal plane } \\
\text { direct beam solar radiation } \\
\text { anisotropic reduction factor for tilted surface } \\
\text { diffuse radiation from: the Rayleigh diffusion, } \\
\text { aerosols diffusion and multi reflection } \\
\text { monthly mean hourly and daily diffuse solar } \\
\text { radiation on horizontal plane } \\
\text { diffuse and GSR on inclined plane } \\
\text { mean maximum minus mean minimum }\end{array}$} & $\begin{array}{l}F_{1}, F_{2} \\
f_{k} \\
F_{M} \\
\overline{\overline{G_{H}}} \overline{G_{H}} \\
G S R \\
H A \\
H D K R \\
h_{n} \\
I_{s c} \\
I_{0} \\
K \\
m_{\text {air }} \\
m_{f} \\
N_{g} \\
R \\
R_{b}\end{array}$ & $\begin{array}{l}\text { tempe } \\
\text { circum } \\
\text { detern } \\
\text { compc } \\
\text { month } \\
\text { plane } \\
\text { global } \\
\text { hourly } \\
\text { Hay-D } \\
\text { height } \\
\text { extrate } \\
\text { extrate } \\
\text { climati } \\
\text { air ma } \\
\text { air ma } \\
\text { Gueyn } \\
\text { sun-ec } \\
\text { ratio o } \\
\text { plane }\end{array}$ & $\begin{array}{l}\text { rature in }{ }^{\circ} \mathrm{C} \\
\text { nsolar and bri } \\
\text { mine the degr } \\
\text { osite clearnes } \\
\text { ly mean hour } \\
\text { I solar radiatic } \\
\text { absolute mo } \\
\text { avies-Kluche } \\
\text { t of the sun at } \\
\text { errestrial sola } \\
\text { errestrial radi } \\
\text { tic zone parar } \\
\text { ass } \\
\text { ass corrected } \\
\text { mard's weigh } \\
\text { arth distance } \\
\text { of the direct ro } \\
\text { to that on ho }\end{array}$ & $\begin{array}{l}\text { ghtness of the } \\
\text { ee of cloud cove } \\
\text { s function } \\
\text { ly and daily GS } \\
\text { del } \\
\text { r- Riendl model } \\
\text { noon } \\
\text { r constant (136 } \\
\text { ation on normal } \\
\text { neter } \\
\text { for elevation } \\
\text { ing factor for clc } \\
\text { correlation facto } \\
\text { diation incident } \\
\text { izontal plane }\end{array}$ & $\begin{array}{l}\text { orizon } \\
\text { on horizontal } \\
\text { plane } / \mathrm{m}^{2} \text { ) } \\
\text { ud opacity } \\
\text { on an inclined }\end{array}$ \\
\hline
\end{tabular}




\begin{tabular}{|ll|}
\hline$R_{d 0}, R_{d 1}$ & factors for clear or overcast sky \\
$R_{H}$ & relative humidity \\
$t$ & true solar time \\
$T_{M}$ & ratio of diffuse radiation on the tilted surface to \\
& that on horizontal \\
$W$ & atmospheric water vapor content per unit volume \\
& of dry air \\
$\alpha_{o}, \alpha_{w}$ & absorption coefficient of the direct radiation by \\
& ozone layer and water vapor \\
$\beta$ & tilt angle \\
$\theta_{Z}$ & zenith angle \\
$\rho$ & ground albedo \\
$\rho_{S}^{\prime}$ & absorption coefficient by the ozone layer \\
$\sigma^{\prime}$ & standard deviation of the Gaussian curve \\
$T_{a}, T_{r}$ & aerosols and Rayleigh diffusion \\
$T_{b u l k}$ & bulk atmospheric transmittance \\
$T_{D}$ & atmospheric attenuation \\
$T_{o}$ & absorption by ozone \\
$T_{T}$ & total transmittance \\
\hline
\end{tabular}

\section{References}

[1] http://www.energy.gov.dz n.d.

[2] Bekkouche SMA, Benouaz T, Yaiche MR, Cherier MK, Hamdani M, Chellali F. Introduction to control of solar gain and internal temperatures by thermal insulation, proper orientation and eaves. Energy Build 2011;43:2414-21.

doi:10.1016/j.enbuild.2011.05.018.

[3] Stambouli AB, Khiat Z, Flazi S, Kitamura Y. A review on the renewable energy development in Algeria: Current perspective, energy scenario and sustainability issues. Renew Sustain Energy Rev 2012;16:4445-60. doi:10.1016/j.rser.2012.04.031.

[4] Boukelia TE, Mecibah M, Meriche IE. General Models for Estimation of the Monthly Mean Daily Diffuse Solar Radiation (Case Study: Algeria ). Energy Convers Manag 2014;81:211-9.

doi:10.1016/j.enconman.2014.02.035.

[5] ONM. Catalogue des produits et services de Météo Algérie 2015. http://www.meteo.dz/catalogueonligne.php (accessed April 11, 2017).

[6] Paulescu M, Paulescu E, Gravila P, Badescu V. Weather Modeling and Forecasting of PV Systems Operation. Springer; 2013. doi:10.1007/978-1-4471-4649-0.

[7] Yacef R, Mellit A, Belaid S, Şen Z. New combined models for estimating daily global solar radiation from measured air temperature in semi-arid climates: Application in Ghardaïa, Algeria. Energy Convers Manag 2014;79:606-15.

doi:10.1016/j.enconman.2013.12.057.

[8] Dahmani K, Notton G, Voyant C, Dizene R, Nivet ML, Paoli C, et al. Multilayer Perceptron approach for estimating 5-min and hourly horizontal global irradiation from exogenous meteorological data in locations without solar measurements. Renew Energy 2016;90:26782. doi:10.1016/j.renene.2016.01.013.

[9] Behar O, Khellaf A, Mohammedi K. Comparison of solar radiation models and their validation under Algerian climate - The case of direct irradiance. Energy Convers Manag 2015;98:236-51. doi:10.1016/j.enconman.2015.03.067.

[10] Mefti A, Adane AEH, Bouroubi MY. Satellite approach based on cloud cover classification: Estimation of hourly global solar radiation from meteosat images. Energy Convers Manag 2008;49:652-9. doi:10.1016/j.enconman.2007.07.041.

[11] Yaiche MR, Bouhanik A, Bekkouche SMA, Benouaz T. A new modelling approach intended to develop maps of annual solar irradiation and comparative study using satellite data of Algeria. J Renew Sustain Energy 2016;8:043702. doi:10.1063/1.4958993

[12] Gairaa K, Bakelli Y. Solar Energy Potential Assessment in the Algerian South Area: Case of Ghardaia Region. Hindawi J Renew Energy 2013. doi:10.1155/2013/496348.

[13] Gairaa K, Bakelli Y. An overview of global solar radiation measurements in Ghardaïa area, south Algeria. Int J ENERGY Environ 2011;2:255-60.

[14] Gairaa K, Benkaciali S. Analysis of solar radiation measurements at Ghardaïa area, south Algeria. Energy Procedia 2011;6:1229. doi:10.1016/j.egypro.2011.05.014.

[15] Capderou M. Atlas Solaire de l'Algérie. Office des. 1985

[16] Gairaa K, Khellaf A, Chellali F, Benkaciali S, Bakelli Y, Bezari S. Maximisation and Optimisation of the Total Solar Radiation Reaching the Solar Collector Surfaces. In: Dincer I, Colpan CO, Kizilkan O, Ezan MA, editors. Prog. Clean Energy, vol. 2, Cham: Springer International Publishing; 2015, p. 873-86. doi:10.1007/978-3-319-17031-2.

[17] Gairaa K, Bakelli Y. A Comparative Study of Some Regression Models to Estimate the Global Solar Radiation on a Horizontal Surface from Sunshine Duration and Meteorological Parameters for Ghardaia Site , Algeria. Hindawi J Renew Energy 2013. doi:10.1155/2013/754956.

[18] Gairaa K, Benkaciali S. Modélisation numérique des irradiations globale et diffuse au site de Ghardaïa. Rev Des Energies Renouvelables 2008;11:129-36.

[19] Benkaciali S, Gairaa K. Techniques de modélisations de l'irradiation solaire sur un plan incliné. Int J Sci Res Eng Technol 2015;3:102-8.

[20] Benkaciali S, Gairaa K. Modélisation de l'irradiation solaire globale incidente sur un plan incliné. Rev Des Energies Renouvelables 2014;17:245-52.

[21] Benkaciali S, Gairaa K. Comparative study of two models to estimate solar 
radiation on an inclined surface. Rev Des Energies Renouvelables 2012;15:219-28.

[22] Talbi K, Harrouni S. Modeling of solar radiation received at ground level using semi empirical models for short time scales. 8th Int. Conf. Model. Identif. Control. ICMIC-2016, 2016, p. 603-7. doi:10.1109/ICMIC.2016.7804182.

[23] Yaiche MR, Bekkouche SMA. Conception et validation d'un logiciel sous Excel pour la modélisation d'une station radiométrique en Algérie Cas d'un ciel totalement clair. Rev Des Energies Renouvelables 2009;12:67788.

[24] Yaiche MR, Bekkouche SMA. Estimation du rayonnement solaire direct en Algérie Cas d'un ciel clair. Rev Des Energies Renouvelables 2011;14:461-7.

[25] Zaatri A, Azzizi N. Evaluation of some mathematical models of solar radiation received by a ground collector. World $\mathrm{J}$ Eng 2016;13:376-80. doi:10.1108/WJE-08-2016050.

[26] Benmouiza K. Quantification of Solar Radiation in Algeria, Application to the Sizing of Photovoltaic Systems. ABOU BEKR BELKAID - TLEMCEN, 2015.

[27] Mesri M. Numerical methods to calculate solar radiation, validation through a new Graphic User Interface design. Energy Convers Manag 2015;90:436-45. doi:10.1016/j.enconman.2014.11.037.

[28] Mesri M, Choucha A, Chaib L. Evaluation of Global Solar Radiation Models for Inclined Surfaces. Int. Conf. Electr. Autom. Mech. Eng. EAME 2015, 2015, p. 478-81.

[29] Mesri M, Rougab I, Cheknane A, Bachari NI. Estimation du rayonnement solaire au sol par des modèles semi-empiriques. Rev Des Energies Renouvelables 2012;15:451-63.

[30] Asradj Z, Alkama R, Demir S, Tekin A. MLP/Levenberg-Marquardt for Prediction Solar Radiation: A Case Study Bejaia City. In: Oral A., Bahsi Oral Z., Ozer M, editors. 2nd Int. Congr. Energy Effic. Energy Relat. Mater., Cham: Springer International Publishing; 2015, p. 53-60. doi:10.1007/978-3-31916901-9.

[31] Bouzid Z, Ghellai N, Benmedjahed M. Estimation of Solar Radiation, Management of Energy Flow and Development of a New Approach for the Optimization of the Sizing of Photovoltaic System; Application to Algeria. Int J Renew Energy Res 2015;5.

[32] Bouzid Z, Ghellai N. Estimation of Solar Radiation on Inclined Surface and Design Method for an Autonomous Photovoltaic System . Application to Algeria. Int. Renew. Sustain. Energy Conf. IRSEC, IEEE; 2015, p. 1-6. doi:10.1109/IRSEC.2015.7454931.

[33] Mecibah MS, Boukelia TE, Benyahia NE. Management and exploitation of direct normal irradiance resources for concentrating solar collectors: Algeria as a case study. Int J Energy Environ Eng 2015;6:65-73. doi:10.1007/s40095-014-0151-z.
[34] Mecibah MS, Boukelia TE, Tahtah R, Gairaa K. Introducing the best model for estimation the monthly mean daily global solar radiation on a horizontal surface (Case study: Algeria). Renew Sustain Energy Rev 2014;36:194-202. doi:10.1016/j.rser.2014.04.054.

[35] Boukelia TE, Mecibah MS, Meriche IE. Estimation the DNI from global and diffuse horizontal irradiance for Algeria. 3rd Int. Symp. Environ. Friendly Energies Appl. EFEA2014, IEEE; 2014. doi:10.1109/EFEA.2014.7059967.

[36] Boukelia TE, Mecibah MS. Sunshine based models for estimation of monthly mean daily global solar radiation (Case studies of two south-western locations in Algeria). Int. Conf. Electr. Eng. CIGE2013, 2013.

[37] Boukelia TE, Mecibah MS. Estimation of direct solar irradiance intercepted by a solar concentrator in different modes of tracking (case study: Algeria). Int J Ambient Energy 2013:1-8. doi:10.1080/01430750.2013.864587.

[38] Boukelia TE, Mecibah MS. Simulation of solar radiation intercepted by solar concentrator in different modes of tracking installed in three different Algerian locations. Int. Conf. Electr. Eng. Autom. Control. ICEEAC 2013, 2013.

[39] Ouali K, Alkama R. A new model of global solar radiation based on meteorological data in Bejaia City (Algeria). Energy Procedia 2014:50:670-6. doi:10.1016/j.egypro.2014.06.082.

[40] Nia M, Chegaar M, Benatallah MF, Aillerie M. Contribution to the Quantification of Solar Radiation in Algeria. Energy Procedia 2013;36:730-7. doi:10.1016/j.egypro.2013.07.085

[41] Azzouni M, Kabouche N, Barazane L, Kharzi S. Modeling of Athmospheric Phenomena for Photovoltaic Ssystems. 3rd Int. Conf. Syst. Control. ICSC 2013, 2013. doi:10.1109/ICoSC.2013.6750942.

[42] Salmi M, Chegaar M, Mialhe P. Modèles d'Estimation de l'Irradiation Solaire Globale sur une Surface Horizontale au Sol. Rev Int d'Héliotechnique 2007;35:19-24.

[43] Salmi M, Chegaar M, Mialhe P. A Collection of Models for the Estimation of Global Solar Radiation in Algeria. Energy Sources 2011;6:187-91. doi:10.1080/15567240903485949.

[44] Salmi M, Hassen B, Al-Douri Y, Boursas A. Evaluation of the Hourly Global Solar Radiation on a Horizontal Plane for Two Sites in Algeria. Adv Mater Res 2014;925:641-5. doi:10.4028/www.scientific.net/AMR.925.641.

[45] Chikh M, Mahrane A, Haddadi M. Modeling the diffuse part of the global solar radiation in Algeria. Energy Procedia 2012;18:1068-75. doi:10.1016/j.egypro.2012.05.121.

[46] Chikh M, Maafi A, Malek A. Etablissement d'un Modèle Mathématique 
pour la Fraction Diffuse de l'Irradiation Solaire en Algérie. Rev Des Energies Renouvelables 2000:75-81.

[47] Chikh M, Maafi A, Malek A. Corrélation de la Fraction Diffuse de I'Irradiation Solaire en Algérie. Rev Des Energies Renouvelables 1999:125-9.

[48] Aksas M, Gama A. Assessment of wind and solar energy resources in Batna, Algeria. Energy Procedia 2011;6:459-66. doi:10.1016/j.egypro.2011.05.053.

[49] Hamdani M, Bekkouche SMA, Benouaz T, Cherier MK. Etude et Modélisation du Potentiel Solaire Adéquat pour l'Estimation des Eclairements Incidents à Ghardaïa. Rev Int d'Héliotechnique 2011;43:8-13.

[50] Koussa M, Malek A, Haddadi M. Statistical Comparison of Monthly Mean Hourly and Daily Diffuse and Global Solar Irradiation Models and a Simulink Program Development for Various Algerian Climates. Energy Convers Manag 2009;50:1227-35. doi:10.1016/j.enconman.2009.01.035.

[51] Koussa M, Malek A, Haddadi M, Haddadi EM. Proposition d'une Méthodologie de Reconstitution des Moyennes Mensuelles par Heure des Irradiation Diffuse et Globale en Fonction des Moyennes Mensuelles par Jour de Quelques Paramètres Météorologiques. Rev. des Energies Renouvelables, Tlemcen: 2007, p. 255-68.

[52] Yettou F, Malek A, Haddadi M, Gama A. Etude comparative de deux modèles de calcul du rayonnement solaire par ciel clair en Algérie. Rev Des Energies Renouvelables 2009;12:331-46.

[53] Mefti A, Bouroubi MY, Adane AEH. Generation of Hourly Solar Radiation for Inclined Surfaces Using Monthly Mean Sunshine Duration in Algeria. Energy Convers Manag 2003;44:3125-41. doi:10.1016/S01968904(03)00070-0.

[54] Mefti A, Bouroubi MY, Khellaf A. Analyse Critique du Modèle de l'Atlas Solaire de l'Algérie. Rev Phys Appliquée 1999;2:69-85.

[55] Chegaar M, Chibani A. Global Solar Radiation Estimation in Algeria. Energy Convers Manag 2001;42:967-73. doi:10.1109/IREC.2014.6826904.

[56] Chegaar M, Chibani A. A Simple Method for Computing Global Solar Radiation. Rev Des Energies Renouvelables 2000:111-5.

[57] Mefti A, Adane AEH, Delorme C. Estimation of Solar Irradiance Using WEFAX and High Resolution Meteosat Images. World Renew. Energy Congr. VI, 2000, p. 2539-42.

[58] Boulifa M, Adane AEH, Rezagui A, Ameur Z. Estimate of the Global Solar Radiation by Cloudy Sky Using HRV Images. Energy Procedia 2015;74:1079-89. doi:10.1016/j.egypro.2015.07.747.

[59] Boulifa M, Adane AEH, Mefti A, Ameur S, Ameur Z. The Solar Radiation Evaluation by Satellite Images Processing. Int. Conf. Renew. Energies Power Qual., RE\&PQJ; 2010, p. 344-7.
[60] Tadj M, Benmouiza K, Cheknane A. Hourly Solar Radiation Based on Improved GISTEL Model. 3rd Int. Semin. New Renew. Energies, 2014.

[61] Meziani F, Boulifa M, Ameur $Z$. Determination of the Global Solar Irradiation by MSG-SEVIRI Images Processing in Algeria. Energy Procedia 2013;36:525-34. doi:10.1016/j.egypro.2013.07.061.

[62] Yaiche MR, Bouhanik A, Bekkouche SMA, Malek A, Benouaz T. Revised solar maps of Algeria based on sunshine duration. Energy Convers Manag 2014;82:114-23. doi:10.1016/j.enconman.2014.02.063.

[63] Yaiche MR, Bouhanik A. Atlas solaire Algerien 2014. http://www.cder.dz/IMG/pdf/Atlas_solaire_Alg erien CDER.pdf.

[64] Abdeladim K, Bouchakour S, Hadj Arab A, Cherfa F, Semaoui S, Rezagui A. Solar Assessment in Algeria Using Retscreen Database. 3rd Eur. Conf. Renew. Energy Syst. ECRES, At Antalya, Turkey: 2015, p. 16.

[65] Abdeladim K, Hadj Arab A, Chouder A, Cherfa F, Bouchakour S, Kerkouche K. Contribution for Solar Mapping in Algeria. In: Dincer I, Midilli A, Kucuk H, editors. Prog. Sustain. Energy Technol. Gener. Renew. Energy, Springer International Publishing; 2014 , p. 439-47. doi:10.1007/978-3-31907896-0 26

[66] Abdeladim K, Bouchakour S, Hadj Arab A, Cherfa F, Chouder A, Kerkouche K. Contribution for Solar Assessment and Mapping in Algeria Using Appropriate Models. 28th Eur. Photovolt. Sol. Energy Conf. Exhib., 2013, p. 3477-81.

[67] Mellit A, Kalogirou SA, Shaari S, Salhi H, Hadj Arab A. Methodology for Predicting Sequences of Mean Monthly Clearness Index and Daily Solar Radiation Data in Remote Areas: Application for Sizing a Stand-Alone PV System. Renew Energy 2008;33:1570-90. doi:10.1016/j.renene.2007.08.006.

[68] Youcef Ettoumi F, Mefti A, Adane AEH, Bouroubi MY. Statistical analysis of solar measurements in Algeria using beta distributions. Renew Energy 2002;26:47-67. doi:10.1016/S0960-1481(01)00100-8.

[69] Youcef Ettoumi F, Mefti A, Bouroubi MY, Adane AEH. Fourier Analysis of Monthly Sunshine Duration for Algeria. World Renew. Energy Congr. VI, 2000, p. 2543-6.

[70] Mefti A, Bouroubi MY. Estimation et Cartographie de la Composante Globale du Rayonnement Solaire. Rev Des Energies Renouvelables 1999:219-24.

[71] Messen N. The iso-radiation map for Algeria. Sol Wind Technol 1990;7:559-62. doi:10.1016/0741-983X(90)90064-9.

[72] Ramli MAM, Twaha S, Al-turki YA. Investigating the performance of support vector machine and artificial neural networks in predicting solar radiation on a tilted surface: Saudi Arabia case study. Energy 
Convers Manag 2015:105:442-52. doi:10.1016/j.enconman.2015.07.083.

[73] Harrouni S. A New Predicting Method for Long-Term Photovoltaic Storage Using Rescaled Range Analysis: Application to Two Algerian Sites. J Math Model Algorithms Oper Res 2012;12:311-28. doi:10.1007/s10852012-9189-1.

[74] Harrouni S. Fractal Classification of Typical Meteorological Days from Global Solar Irradiance: Application to Five Sites of Different Climates. Model. Sol. Radiat. Earth's Surf. Recent Adv., 2008, p. 29-54. doi:10.1007/978-3-540-77455-6_2.

[75] Maafi A, Harrouni S. Measuring the Fractal Dimension of Solar Irradiance in View of PV Systems Performance Analysis. World Renew. Energy Congr. VI, 2000, p. 2032-5.

[76] Djafer D, Irbah A, Zaiani M. Identification of clear days from solar irradiance observations using a new method based on the wavelet transform. Renew Energy 2017;101:347-55. doi:10.1016/j.renene.2016.08.038.

[77] Benmouiza K, Tadj M, Cheknane A. Classification of Hourly Solar Radiation Using Fuzzy c-means Algorithm for Optimal StandAlone PV System Sizing. Int J Electr Power Energy Syst 2016;82:233-41. doi:10.1016/j.ijepes.2016.03.019.

[78] Benmouiza K, Cheknane A. DensityBased Spatial Clustering of Application with Noise Algorithm for the Classification of Solar Radiation Time Series. 8th Int. Conf. Model. Identif. Control. ICMIC-2016, 2016, p. 27983. doi:10.1109/ICMIC.2016.7804123.

[79] Benmouiza K, Tadj M, Cheknane A. Classification of the Hourly Solar Radiation Using k-means and Fuzzy c-means Algorithms. 3rd Int. Semin. New Renew. Energies, 2014

[80] Vindel JM, Polo J. Intermittency and variability of daily solar irradiation. Atmos Res 2014;143:313-27. doi:10.1016/j.atmosres.2014.03.001.

[81] Harrouni S, Guessoum A, Min M. Fractal Classification of solar Irradiances into typical days using a cumulative distribution function Key words. Int. Conf. Renew. Energies Power Qual. ICREPQ'03, Vigo (Spain): 2003, p. 911.

[82] Harrouni S, Maafi A. Classification des Eclairements Solaires à l'Aide de l'Analyse Fractale. Rev Des Energies Renouvelables 2002:5:107-22.

[83] Maafi A, Harrouni S. Preliminary Results of the Fractal Classification of Daily Solar Irradiances. Sol Energy 2003;75:53-61. doi:10.1016/S0038-092X(03)00192-0.
[84] Koussa M, Saheb-Koussa D, Hadji S. Experimental investigation of simple solar radiation spectral model performances under a Mediterranean Algerian's climate. Energy 2017; 120:751-773 doi:10.1016/j.energy.2016.11.132

[85] Mraoui A, Khelif M, Benyoucef B. Optimum tilt angle of a photovoltaic system: Case study of Algiers and Ghardaia. 5th Int Renew Energy Congr IREC 20142014. doi:10.1109/IREC.2014.6826904. 